\title{
The Impact of Corporate Social Responsibility on Regulatory Comment Letters: Evidence from Iran
}

\section{Reza Hesarzadeh}

a) Ferdowsi University of Mashhad, IRAN.

\footnotetext{
${ }^{a}$ Corresponding author
}

E-mail address: Hesarzadeh@um.ac.ir

\section{A R T I C LE I N F O}

\section{Article history:}

Received 9 October 2019

Accepted 4 July 2020

Available online 1 January 2022

\section{JEL classification:}

G12

G14

G18

M48

\section{Keywords:}

CSR

Oversight

Comment letter

Spillover effect

Managers

Emerging markets

\begin{abstract}
A B S T R A C T
Securities commissions regularly review corporate reports, and if the review reveals a possible deficiencysuch as a potential accounting error- or requires further clarifications, they send the company a comment letter (CL), including a request for providing written responses and relative additional information. Current study aims to examine whether and how corporate social responsibility (CSR) affects CLs. This empirical study is based on a sample of 437 Iranian firm year observations from 2011 to 2017. Results show that firms with more CSR are less likely to receive CL, that more CSR does not influence the association of managerial misbehavior and CLs, and that the negative association between CSR and CLs is stronger among firms facing higher environmental information asymmetry and firms having higher corporate governance quality. Collectively, this paper contributes to the literature by providing new evidence on the beneficial effect of CSR in the context of CLs.
\end{abstract}

(C)2022 ASEPUC. Published by EDITUM - Universidad de Murcia. This is an open access article under the CC BY-NC-ND license (http://creativecommons.org/licenses/by-nc-nd/4.0/).

El impacto de la responsabilidad social de las empresas en las cartas de comentarios regulatorios: Evidencia de Irán

RES U M E N

Las comisiones de valores revisan periódicamente los informes de las empresas, y si la revisión revela una posible deficiencia -como un posible error contable- o se requiere más aclaraciones, envían a la empresa una carta de comentarios (CL), que incluye una solicitud de respuesta por escrito y la relativa información adicional. El presente estudio pretende examinar si la Responsabilidad Social de las Empresas (RSE) afecta a las cartas de comentarios y cómo lo hace. Este estudio empírico se basa en una muestra de 437 observaciones anuales de empresas iraníes desde 2011 hasta 2017. Los resultados muestran que las empresas con más RSC tienen menos probabilidades de recibir CL y que más RSC no influye en la asociación entre mal comportamiento de los directivos y CL. También se pone de manifiesto que la asociación negativa entre RSC y CL es más fuerte entre las empresas que enfrentan una mayor asimetría de información ambiental y las empresas que tienen una mayor calidad de gobierno corporativo. En conjunto, este trabajo contribuye a la literatura aportando nuevas pruebas sobre el efecto beneficioso de la RSC en el contexto de las CL.

(C)2022 ASEPUC. Publicado por EDITUM - Universidad de Murcia. Este es un artículo Open Access bajo la licencia CC BY-NC-ND (http://creativecommons.org/licenses/by-nc-nd/4.0/). 


\section{Introduction}

Corporate social responsibility (CSR) describes a company's commitments in caring for the social-environmental dimensions of its operations (e.g., Paredes-Gazquez et al., 2016; Brooks \& Oikonomou, 2018; Larrán et al., 2018; Tan et al., 2020). Literature (e.g., Dhaliwal et al., 2012; Deng et al., 2013; Elliott et al., 2014; Naughton et al., 2018; LópezGonzález et al., 2019; Tomas Siueia \& Wang, 2019), indicates that through CSR, companies display their corporate transparency, signal their managerial integrity and future financial performance, improve their corporate reputation, and protect value for the shareholders (e.g., Dhaliwal et al., 2012; Deng et al., 2013; Elliott et al., 2014; Christensen, 2016; Paredes-Gazquez et al., 2016; Brooks \& Oikonomou, 2018; Larrán et al., 2018). Thus, information about CSR performance has become increasingly useful to stakeholders in their decision-making.

Despite the usefulness of CSR for decisions of various stakeholders - such as financial analysts (e.g., Dhaliwal et al., 2012), shareholders (e.g., Dhaliwal et al., 2011), creditors (e.g., Tan et al., 2020); employees (e.g., Christensen et al., 2017), customers (e.g., Servaes \& Tamayo, 2013) and corporate managers (e.g., Christensen, 2016) - there is relatively little empirical evidence regarding the usefulness of CSR for decisions or actions of regulators, especially regulators in capital markets (e.g., Liu et al., 2018).

To address this research gap, this paper aims to study the impact of CSR on the intensity of regulatory oversight provided by securities commissions. Specifically, the paper investigates whether variation in CSR affects the issuance of comment letters (CLs). The CL as one of the most important oversight mechanisms for securities commissions (e.g., Brown et al., 2018; Cassell et al., 2019), is a letter from a securities commission that is sent to a company, when the securities commission identifies a possible deficiency, such as a potential accounting error, or requires further clarification (Brown et al., 2018; Cassell et al., 2019; Cunningham et al., 2020). In this regard, current study will theoretically discuss and predict that securities commission uses CSR as a "heuristic cue" (e.g., Linthicum et al., 2010; Fernbach \& Rehder, 2013; Chen et al., 2015) and therefore, firms with more CSR are less probably to be scrutinized and less likely to receive a CL. This paper uses CLs issued by the Securities and Exchange Organization (SEO) of Iran. Consequently, the research sample contains companies listed on the Iranian capital market over the period 2011 to 2017. This is an appropriate research setting because of the following reasons. On the one hand, while CSR disclosure worldwide is still predominantly unaudited (e.g., Cohen \& Simnett, 2015; Carey et al., 2017), in Iran, external auditors must review CSR information to obtain moderate assurance as to whether the disclosures are free of material misstatement (SEO, 2007). Therefore, the reliability of CSR information in Iran is relatively high. On the other hand, SEO is under very high workload pressure, because SEO in the last line of defense in policing corporate reporting quality should compensate for the poor institutional setting (e.g., Hesarzadeh, 2020). Further, in Iran's capital market, similar to other developing capital markets, it is not easy to access the diverse sources of information (Su et al., 2014). These characteristics make SEO rely more on CSR and its signaling effect. In addition, the Iranian capital market contains not only mature, large companies, but also a significant proportion of young, small companies. Hence, this research setting enables us to generalize research results to a variety of cases, ranging from high-growth, young and small companies to stable, large and mature companies.

Results show that CSR negatively affects CLs, and that the negative association between CSR and CLs is stronger among firms that face higher environmental information asymmetry and firms with higher corporate governance quality. The paper also documents evidence consistent with the spillover effect of CSR, in the sense that more CSR of peer firms increases a firm's CL. Collectively, the findings provide evidence on the internalities and externalities of CSR in the context of CLS. This study makes important contributions. On the one hand, the study enriches the literature on the consequences of CSR (e.g., Dhaliwal et al., 2011; Brooks \& Oikonomou, 2018; López-González et al., 2019; Tomas Siueia \& Wang, 2019). Further, this study extends the literature by presenting evidence on how the consequences of CSR may be reinforced. On the other hand, this study extends the stream of research has formed to explore the determinants of public enforcement. Particularly, the study enriches the emerging literature (e.g., Robinson et al., 2011; Cassell et al., 2013; Johnston \& Petacchi, 2017; Ballestero \& Schmidt, 2019) on the determinants of receiving CLs by introducing a new factor (i.e., CSR) that reduces CLs.

\section{Literature Review and Hypothesis Development}

\subsection{Corporate Social Responsibility}

In recent decades, few topics have drawn more attention from practitioners than CSR (Bae et al., 2020). Unruh et al. (2016) report that approximately $90 \%$ of top managers believe that CSR is vital to remaining competitive. Academics scholars have responded to this burgeoning interest, spurring a large body of literature, with most attention given to understanding the association of CSR and diverse economic consequences.

Briefly, the scholars suggest that the value of CSR majorly lies in corporate reputation (e.g., Flammer, 2013; Golden et al., 2018), and this corporate reputation leads to diverse favorable outcomes such as better consumer support (e.g., Lev et al., 2009), better choice between bank debt and public debt (Tan et al., 2020), the decrease of cost of equity (e.g., Dhaliwal et al., 2012), and the increase in firm value (e.g., Harjoto \& Jo, 2015).

Compared to these functions, the risk management functions of CSR are less discussed and have few empirical investigations (Francis \& Armstrong, 2003; Peloza, 2006; Bonsón \& Bednárová, 2015). From a risk management perspective, CSR can provide insurancelike protection during difficult times (Bae et al., 2020). For example, CSR can minimize any reactions and penalties when a firm is facing the exposure of wrongdoing (Bonsón \& Bednárová, 2015). As Kytle \& Ruggie (2005) mention, CSR is related to risk management through two mechanisms: by providing intelligence about what those risks are and by offering an effective means to respond them. The key to both is more effectively managing stockholder relationship. Specifically, in the event of a crisis, the moral capital accumulated through CSR can help decouple any illegitimate activity from the rest of the organization (Bansal \& Clelland, 2004). Further, CSR influences consumers' attributions of blame when there is a product crisis, and that CSR reduces negative brand evaluations (Klein \& Dawar, 2004). In this regard, Godfrey (2005) demonstrates that better CSR provides some degree of insurance protection against the risk of market, political, regulatory, and social sanctions when negative corporate events occur. Hong \& Kacperczyk (2009) find that firms with irresponsible behavior face a higher level 
of litigation risk than other firms. Similarly, Starks (2009) and El Ghoul et al. (2011) find that stakeholders perceive socially irresponsible firms as high risky firms. Relatedly, Koh et al. (2013) show that, for firms with a high risk of securities litigation, CSR has a positive effect on firm value due to its ex ante insurance against the risk of securities lawsuits. However, the authors do not explicitly test whether CSR reduces the probability of securities class action lawsuits. Distinct from the aforementioned research, I examine whether CSR has implications for CLs, an important attribute of firms' regulatory risks.

CSR may also protect companies against negative events whose causes are purely external. In this regard, Schnietz \& Epstein (2005) show that a reputation for social responsibility protect a firm's stock price in the general decline associated with the collapse of World Trade Organization talks in Seattle in 1999.

Regarding CSR in Iran, comparable to the most of countries, it is a voluntary activity. Iranian companies that tend to report their social activities usually follow the SEO guideline on CSR reporting. This guideline, comparable to other regulations in the world — such as Directive 2014/95/EU (European commission, 2014) - covers information on the policies which companies implement in relation to the environmental protection, social responsibility and treatment of employees, anti-corruption and bribery, and diversity on company boards. Furthermore, the guideline encourages companies to report the aforementioned information in section Management discussion and analysis (MD\&A) of annual reports. In accordance with Regulations on Disclosure of Information (SEO, 2007), external auditors must review MD\&A to obtain moderate assurance as to whether the disclosures are free of material misstatement. For this reason, the reliability of CSR in Iran is relatively high. Empirical research (Jalili \& Gheisari, 2013; Fakhari et al., 2017; Ghaderi et al., 2019) indicates that CSR is important for Iranian market players. For example, Fakhari et al. (2017) shows that CSR reduces information asymmetry and increases investment efficiency.

\subsection{Regulatory Comment Letters}

Securities commissions have designed the regulatory review process to protect investors (Duro et al., 2018). They periodically review financial statement filings to ensure compliance with disclosure requirements, and if a filing is deemed to be deficient in some way or if the securities commissions desire further information, they issue CLs to companies to require changes to publicly reported information or request additional information (Bills et al., 2019). Consequently, companies should provide written responses and relative additional information (Cunningham et al., 2020; Brown et al., 2018).

Research about how companies craft responses to securities commissions inquires is limited, likely due to the inability of researchers to gain insight into such process (Ballestero \& Schmidt, 2019). Recently, Cassell et al. (2019) investigate the association between the readability of companies' responses to regulatory comment letters, and find that companies having less readable responses face higher remediation costs.

In turn, the research has investigated the determinates and consequences of receiving a CL. Research on the determinates of receiving a CL (e.g., Robinson et al., 2011; Cassell et al., 2013; Johnston \& Petacchi, 2017; Ballestero \& Schmidt, 2019; Hesarzadeh and Rajabalizadeh, 2020) provides evid- ence that CL receipt is more likely for companies that are large, older, more volatile, unprofitable, complex, engage smaller auditors, have recent IPO, or have weak corporate governance, managerial ability, and financial reporting. Furthermore, research on the consequences of receiving a CL (e.g., Gietzmann \& Pettinicchio, 2014; Bozanic et al., 2017; Johnston \& Petacchi, 2017; Brown et al., 2018; Duro et al. 2018; Cassell et al., 2019; Yao \& Xue, 2019; Cunningham et al., 2020) suggests that, in general, a CL improves information environment, in the form of higher earnings response coefficients, quality of disclosures, and forecast accuracy; and lower internal control opinion shopping, earnings management, abnormal trading volume, return volatility, bidask spread and future stock price crash risk.

Regarding the regulatory review process in Iran, it is relatively comparable to the U.S. securities commission (SEC) review procedure, as the key source to frame review procedure in Iran's capital market, is the SEC review procedure. In according to Iran's Capital Market Act (see Islamic Consultative Assembly, 2005; SEO, 2014), the mission of SEO is to protect investors and enhance market efficiency. Therefore, as part of this mission, the SEO must review/scrutinize the corporate reports. The SEO review process involves evaluating the corporate reports from an investors' perspective and asking questions that investors might ask when reading the disclosure. Upon scrutiny of corporate reports, if questions arise, the SEO issues a CL including possible disclosure deficiency and concerns to the firms. The responses of firms must include new or additional disclosures in the corporate reports (Hesarzadeh and Rajabalizadeh, 2020). The SEO consider the responses and their new or additional disclosures and then, may issue new CLs until all potential deficiencies are resolved. The CL procedure may terminate with the SEO recommending the cases of corporate reporting irregularities to the process of regulatory enforcement and sanctions (Hesarzadeh and Rajabalizadeh, 2020).

Notable, SEO scrutiny procedure has specific/unique characteristics in comparison of SEC scrutiny procedure. In this regard, first, SEO scrutiny procedure is under very high workload pressure. This is because, in Iran's capital market, institutional setting is relatively poor and therefore, to protect investors and enhance market efficiency, SEO in the last line of defense in policing corporate reporting quality should compensate for the poor institutional setting (Hesarzadeh, 2020). Second, SEO scrutiny procedure usually has to focus on corporate disclosures. This is because in Iran's capital market, comparable to other developing capital markets, it is not easy to access the diverse sources of information (e.g, Su et al., 2014) and therefore, SEO scrutiny procedure should majorly focuses on corporate disclosures. In this regard, current study will discuss that SEO reviewers are looking for some heuristic cues to limit the processing of information and therefore, to more efficiently and effectively conclude the reliability of corporate reports. These conditions make SEO rely more on CSR reports and its signaling effect.

\subsection{Hypothesis Development}

CSR can be viewed as a mechanism through which managers build a moral corporate reputation. Generally, this reputation encourages stakeholders to "look the other way" (Kotchen \& Moon, 2012) and may reduce the probability of litigation risks (Baker \& Griffith, 2009; Kim et al., 2012). A positive CSR reputation can encourage stakeholders to view events suggestive of violations as the result of a one-time error and not an intentional act to deceive. Hence, when there 
is a belief in a lack of intent, the motivation to file a lawsuit is likely to be lower.

Particularly, CSR may reduce the risk of receiving a CL because of the following reasons. First, while CL procedures is very time consuming and costly, the securities commissions have to allocate specific and limited human and financial resources to the scrutiny of disclosures (Brown et al., 2018). Under this condition, securities commissions are looking for some heuristic cues to limit the processing of information and therefore, to more efficiently and effectively conclude the reliability of corporate disclosures (Fernbach \& Rehder, 2013; Hesarzadeh and Rajabalizadeh, 2020; Cassell et al., 2019). In this regard, the reviewers of securities commissions use CSR as an important heuristic cue in examining the reliability of corporate disclosures. This is because CSR provides a signal of sincere care about reliable information (Linthicum et al., 2010; Cao et al., 2019) as CSR is a sign of ethics of management (Linthicum et al., 2010; Chen et al., 2015); and company's reputation which will prevent managers from opportunistic behaviors (Linthicum et al., 2010; Rothenhoefer, 2018). Hence, the reviewers of securities commissions probably use CSR as a positive heuristic cue while investigating the reliability of disclosures.

Second, CL procedure is mainly made from the view of investors, that is, the information and the information environment, which are necessary for the investors' decision (SEC, 2015; Bozanic et al., 2017). In this respect, CSR strongly relates to the information and the information environment, which are necessary for the investors' decision (Cho et al., 2013; Ramanna, 2013; Elliott et al., 2014), as CSR can provide wider useful information than financial statements (Ramanna, 2013); shrinks information asymmetry (Cho et al., 2013); and affects economic decisions (Elliott et al., 2014). Thus, since the CL procedure is mainly made from the view of investors, and CSR is important for investors, then the reviewers of securities commissions probably address CSR while assessing the minimum expected quality and quantity of information.

Third, the positive association between CSR financial disclosure's truthfulness suggests that CSR is used by honest managers to really improve information quality and transparency (Jo \& Na, 2012; Scholtens \& Kang, 2012). In this respect, Scholtens \& Kang (2012) point out companies with more CSR have lower earnings manipulation. Barton et al. (2015) extend this finding with evidence showing that better CSR companies manipulate earnings through reduction of financing costs and rather than extraction of rent. Notable, although companies having managerial misbehavior may engage greater CSR (Cho et al., 2013; Tomas Siueia and Wang, 2019), CSR, at least, improves information users' perceptions of the truthfulness of disclosure (Fieseler, 2011; Guiral, 2012). For example, Guiral (2012) reveals that CSR positively influences the perception of auditors about a company's internal control mechanisms. Thus, based on the association of CSR and truthfulness of financial disclosure (or at least based on the association of CSR and perceptions of truthfulness of disclosure), the reviewers of securities commissions may positively address CSR, while choosing the firms for review.

Based on above arguments, this paper expects that firms with more CSR are less probably to be scrutinized and therefore, are less likely to receive a CL. Formally stated:

\section{H1: CSR is inversely associated with CL.}

The demand for corporate reporting majorly stems from environmental information asymmetry (Diamond \& Verrec- chia, 1991; Healy \& Palepu, 2001; Bushman et al., 2011; Cheng \& Wu, 2014; Hesarzadeh, 2020; Burke et al., 2020; $\mathrm{Hu} \& \mathrm{Fu}, 2020$ ), since the information asymmetry is a fundamental principle regarding information search processes, and it initiates the process of information seeking (Hesarzadeh, 2020).

In this regard, for example, Diamond \& Verrecchia (1991) theoretically posit that the information asymmetry can create incentives for information users to search additional information. Further, Cheng \& Wu (2014) show that the effect of corporate information is larger for companies having high environmental information asymmetry.

Particularly, in the context of CSR, Martínez-Ferrero et al (2015), Hickman (2018), and Burke et al. (2020) suggest that, under higher environmental information asymmetry, there is a greater need to CSR information. Particularly, Bae et al. (2020) argue that as environmental information asymmetry increases and, therefore, the credibility of financial information drops, an alternative source of information investors can count on is the firm's nonfinancial voluntary disclosure such as CSR disclosures, as the CSR disclosures matter for the understanding of a company's risks and opportunities (KPMG, 2015). Further, Tan et al. (2020) suggest that higher environmental information asymmetry can result in more demand for and higher reliance on CSR from public debtholders in their risk assessment tasks.

This information asymmetry is also important from CL perspective. For clarity, the reviewers of securities commission scrutinize a firm by evaluating the corporate reports from investors' view and addressing issues that investors might address when reviewing the reports and thus, detect instances that firms should clarify (Brown et al., 2018). Hence, if under higher environmental information asymmetry, investors have greater needs to CSR information, and the reviewers of securities commission scrutinize a firm by addressing issues that investors might address, then we can expect that under higher environmental information asymmetry, the reviewers more likely address CSR, while choosing the firms for review or scrutinizing firms. Furthermore, based on Su et al. (2014), when a firm's environmental information asymmetry is high, the reviewers may search for additional information, like CSR information, to assess the firm's behaviors. Hence, under higher environmental information asymmetry, the reviewers of securities commission more likely address CSR, while choosing the firms for review or scrutinizing firms. Therefore, this paper predicts that the association of CSR and CL is stronger when the environmental information asymmetry is higher. Hence, current paper states its second hypothesis as follows:

\section{H2: Higher environmental information asymmetry} strengthens the association of CSR and CL.

CSR may be driven by moral/honest management or by opportunistic management. Specifically, on the one hand, CSR is enjoyed by moral/honest managers (e.g., Jo \& $\mathrm{Na}$, 2012; Kim et al., 2012; Scholtens \& Kang, 2012; Barton et al., 2015). For example, Kim et al. (2012) and also Barton et al. (2015) show that companies engaging higher CSR have lower earnings manipulation.

On the other hand, managers may employ CSR as an entrenchment strategy, i.e., as a means to cover up managerial misbehavior or to mask their self-serving behaviors (e.g., Surroca \& Tribo, 2008; Burke et al., 2020). For instance, Burke et al. (2020) suggest that managers seek to over-invest in CSR for their private benefit, such as enhancing their own reputation as good citizens, garnering employ- 
ees' and customers' affection, and increasing managers' job security. From this perspective, CSR activities are instead a manifestation of the agency problem between managers and shareholders.

Hence, if the reviewers of securities commissions do not perceive (perceive) the company's CSR as the result of managerial misbehavior or self-serving behaviors, they probably respond by reducing (increasing) scrutiny.

In this regard, corporate governance quality may affect the intuition of the regulatory reviewers about the (positive versus negative) nature of diverse corporate activities (Cassell et al., 2013, 2019; Johnston \& Petacchi, 2017; Ballestero \& Schmidt, 2019; Baugh \& Schmardebeck, 2020; Cunningham et al., 2020; Hesarzadeh, 2020), including CSR. This is because, as Gill (2008) demonstrates, greater corporate governance quality is an appropriate way for pushing managers to more address ethical considerations, therefore, for the firms with greater corporate governance quality, CSR more (less) likely results from moral/honest management (opportunistic management). For instance, Khan et al. (2012) suggest that higher corporate governance quality may reduce some concerns relating to opportunistic CSR. Specifically, Cao et al. (2019) state that companies having CSR with strong (weak) governance are less (more) probably to have an entrenchment strategy. In addition, Nair et al. (2019) discuss that, in firms having weak corporate governance, managers use CSR disclosures for "green washing" which provides noisy information. Furthermore, Shahab and Ye (2018) find that the inclusion of institutional owners, independent board of directors, and large board size in the organizations may lead to increased adherence to the CSR guidelines.

For these reasons, if under higher (lower) corporate governance quality, the reviewers of securities commissions do not perceive (perceive) the company's CSR as the result of managerial misbehavior, they probably respond by reducing (increasing) scrutiny. Thus, to the extent that the reviewers of securities commission pay attention to firms' corporate governance quality, it could be expected that corporate governance quality strengthens the association of CSR and CL. Therefore, current paper states its third hypothesis as follows:

H3: Higher corporate governance quality strengthens the association of CSR and CL.

Figure 1 shows the theoretical associations of CSR, CL, environmental information asymmetry, and corporate governance quality.

Figure 1. Research hypotheses

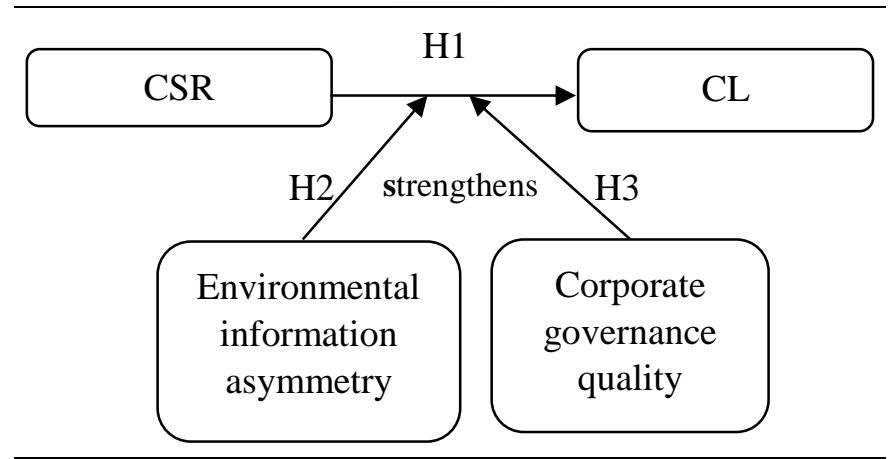

Figure above displays the theoretical associations of main variables.

\section{Methods}

\subsection{Sample}

The research sample focuses on Iran's capital market, namely Tehran Securities Exchange (TSE), and consists of an unbalanced panel of 437 company-years observations over the period of 2011 to 2017 . Table 1 outlines the steps to construct the sample. As shown in the table, the initial research sample comprises 2,219 company-years observations (i.e., 317 companies over seven years). This paper excludes financial/utility companies because of the dissimilarity in various metrics and following literature (e.g., Shahab \& Ye, 2018; Bills et al., 2019; Nair et al., 2019; Tan et al., 2020; Xu \& Yang, 2019; Yao \& Xue, 2019; Cunningham et al., 2020). The paper further eliminates company-years with low trade levels (less than 20 trades) and company-years without the necessary data to compute research variables.

With the exception of data on CL that collected from the SEO, this paper extracts data from the Rahavard Novin, the most comprehensive database in TSE (Hesarzadeh, 2020).

Table 1. Sample selection procedures

\begin{tabular}{lc}
\hline Company-years between $2011-2017[317 \times 7=]$ & 2,219 \\
Less: Utility/financial company-years & $(966)$ \\
Less: Low trade levels company-years & $(503)$ \\
Less: Missing information company-years & $(313)$ \\
\hline Research sample (N) & 437 \\
\hline \multicolumn{1}{c}{ Non-CL company-years } & 346 \\
CL company-years & 91 \\
\hline
\end{tabular}

Table above details the procedure of sample selection.

\subsection{Measuring Variables}

\subsubsection{Corporate Social Responsibility}

To measure CSR, extensive research (Dhaliwal et al., 2011; Cho et al., 2013; Davidson et al., 2019; Rothenhoefer, 2018), employs data from MSCI Inc, which is the successor of Kinder, Lydenberg, Domini \& Co. (KLD). For simplicity, this paper refers to this database as KLD. KLD is an independent investment research firm specializing in compiling rating of firms' CSR and it started to track firms' social performance since1991. Over time, KLD has expanded its coverage and included CSR strengths and weaknesses for a large subset of its constituent firms, including Standard \& Poor's (S\&P) 500, the Domini 400 Social Index, and firms in the Russell 1,000 Index (see, Ramchander et al., 2012; Flammer \& Bansal, 2017; Golden et al., 2018). The KLD scores CSR on dimensions containing "corporate governance, community relations, diversity, employee relations, environment, product, alcohol, gambling, military contracting, nuclear power and tobacco" (Kim et al., 2012).

Since KLD does not cover Iranian firms, this paper uses Iranian KLD, which is based on the same dimensions in KLD and developed by Rahavard Novin Inc. However, this paper, following studies (Dhaliwal et al., 2011; Servaes \& Tamayo 2013; Lins et al., 2017; Davidson et al., 2019; Cao et al., 2019), excludes the last five dimensions as these dimensions do not reflect the firms' discretionary.

In addition, this paper excludes corporate governance dimension because of the following reasons. First, it is generally controversial to consider corporate governance as part of CSR (e.g., Kim et al., 2012; Lins et al., 2017; Cao et al., 2019), 
since CSR includes activities that serve interests of all stakeholders, depending on how one defines shareholders' best interest, corporate governance and CSR may be two completely different constructs (Kim et al., 2012). Further, the relation between corporate governance and CSR may also depend on CSR incentives. For instance, if CSR is motivated by managers' self-interest and good corporate governance works as a disciplinary mechanism, then corporate governance and CSR could be negatively associated (Cao et al., 2019). Second, corporate governance dimension is particularly controversial to the third hypothesis, where this paper investigates how corporate governance quality influences the association of CSR and CL.

In summary, this study constructs the CSR by total strengths minus total concerns in the five dimensions including community, employee relations, diversity, environment and product quality. This paper refers to this Index as Iranian adjusted KLD (AKLD).

\subsubsection{Comment Letter}

Following extensive relevant works (e.g., Cassell et al., 2013, 2019; Cunningham et al., 2020), SEO CL, "CL", is coded as " 1 " (" 0 ") if a company receives (does not receive) a CL on the corporate reports in year t. Figure 2 shows how this paper assigns " 1 " ("0") to each observation.

Figure 2. Visual description of variable $C L$

\begin{tabular}{ll}
\multicolumn{1}{c}{ Year t } & \multicolumn{1}{c}{ Year t+1 } \\
$\begin{array}{l}\text { 1- Firm A prepares its corporate } \\
\text { reports (including CSR disclosure } \\
\text { in annual reports) }\end{array}$ & $\vdots \begin{array}{l}\text { 2- Firm A publishes its } \\
\text { corporate reports }\end{array}$ \\
\hline $\begin{array}{l}\text { 4- } C L \text { is coded as '1' ('0') for } \\
\text { Firm A }\end{array}$ & $\vdots \begin{array}{l}\text { 3- Firm A receives (does } \\
\text { not receives) a CL on its } \\
\text { corporate reports }\end{array}$ \\
&
\end{tabular}

Figure above shows how $C L$ is coded as "1" ("0").

\subsubsection{Environmental Information Asymmetry}

To measure environmental information asymmetry $\left(E_{-} I A\right)$, first, this study measures the information asymmetry and, following Hesarzadeh (2020), employs a statistical principal components methodology to isolate the common component of information asymmetry in these four proxies: "return volatility," "trading volume," "ask-bid spread" and "illiquidity." Then, since the information asymmetry potentially stems from environmental information asymmetry and also poor corporate reporting/internal controls (Zhang, 2006), following the methodology of Francis et al. (2005), this study employs the "residual value of regression of information asymmetry on corporate reporting/internal controls quality metrics" to measure environmental information asymmetry. The corporate reporting quality/internal controls metrics include accruals earnings management, real earnings management, internal control weakness, and restatement.

\subsubsection{Corporate Governance Quality}

Following Lopes et al. (2016), the measure of corporate governance quality, Gov, quantifies the quality of governance exploiting 15 questions regarding to four dimensions: shareholder rights; disclosure; ownership structure \& control; and board performance \& composition (see dimensions 1 to 15 in Exhibit 1 of Lopes et al. (2016)).

\subsubsection{Control Variables}

This study, based on literature (see, for example, Cassell et al., 2013, 2019; Hesarzadeh and Rajabalizadeh, 2020), includes diverse control variables which affect CL. The variables can be classified under three general dimensions, including corporate reporting/internal control quality, corporate characteristics, and corporate governance as follows (see Cassell et al., 2013, and Hesarzadeh and Rajabalizadeh, 2020, for a detailed discussion of this issue):

- corporate reporting/internal control quality, including accruals-based earnings manipulation $\left(A_{-} E M\right)$, real activities based earnings manipulation $\left(R \_E M\right)$, internal control weakness (I_CW), and restate of financial statements (Rest);

- corporate characteristics, including volatility of abnormal stock returns ( $\mathrm{Vol}$ ); market capitalization (M_C), age (Age), incidence of loss (Loss), return on assets $\left(R \_O A\right)$, bankruptcy risk $\left(B \_R\right)$; sales growth $\left(S_{-} G\right)$, external financing $\left(E_{-} F\right)$, and litigation risk $\left(L_{-} R\right)$;

- corporate governance, including auditor size (Big), auditor tenure $\left(A_{-} T\right)$, institutional ownership (I_O), CEOChairman duality (Dual), chief financial officer power $\left(C_{-} P\right.$ ), and board of directors independence (Indep).

\subsection{Test Model}

Consistent with $\mathrm{H} 1$, current paper examines whether CSR affects the probability of receiving a CL. Thus, the predicted variable is CL (operationalized by SEO CL on corporate reporting, $C L$ ). Moreover, the test variable is the CSR (operationalized by modified KLD index, $A K L D$ ). The paper assesses the statistical relationship between CSR and CL by estimating this logistic regression:

$$
\begin{aligned}
& C L_{i t}=\gamma_{0}+\gamma_{1} A K L D_{i t}+\gamma_{2} A_{-} E M_{i t}+\gamma_{3} R \_E M_{i t}+\gamma_{4} I_{-} C W_{i t}+\gamma_{5} \text { Rest }_{i t} \\
& +\gamma_{6} V_{0 l} l_{i t}+\gamma_{7} M_{-} C_{i t}+\gamma_{8} A g e_{i t}+\gamma_{9} \text { Loss }_{i t}+\gamma_{10} R_{-} O A_{i t} \\
& +\gamma_{11} B_{-} R_{i t}+\gamma_{12} S_{-} G_{i t}+\gamma_{13} E_{-} F_{i t}+\gamma_{14} L_{-} R_{i t}+\gamma_{15} B i g_{i t} \\
& +\gamma_{16} A_{-} T_{i t}+\gamma_{17} I_{-} O_{i t}+\gamma_{18} D_{u a l}+\gamma_{19} C_{-} P_{i t} \\
& +\gamma_{20} \text { Indep } p_{i t}+I_{-} F E+Y_{-} F E+\varepsilon_{i t}
\end{aligned}
$$

Furthermore, consistent with $\mathrm{H} 2$ and $\mathrm{H} 3$, current study examines whether environmental information asymmetry and corporate governance quality moderate the association of CSR and CL. Thus, this study empirically examines the relation between CL and both "interaction of CSR and environmental information asymmetry" and "interaction of CSR and corporate governance quality". Technically, current paper assesses the moderating roles of environmental information asymmetry $\left(E_{-} I A\right)$ and corporate governance quality (Gov) by estimating these two regressions:

$$
\begin{gathered}
C L_{i t}=\gamma_{0}+\gamma_{1} A K L D_{i t}+\gamma_{21}\left(E_{-} I A\right)_{i t} \gamma_{22} A K L D_{i t} \times\left(E_{-} I A\right)_{i t} \\
+ \text { Controls }_{i t}+I_{-} F E+Y_{-} F E+\varepsilon_{i t} \\
C L_{i t}=\gamma_{0}+\gamma_{1} A K L D_{i t}+\gamma_{21} G o v_{i t}+\gamma_{22} A K L D_{i t} \times G o v_{i t} \\
+ \text { Controls }_{i t}+I_{-} F E+Y_{-} F E+\varepsilon_{i t}
\end{gathered}
$$

In the logistic regressions above, Controls include all control variables in Equation (1).

This paper defines all of variables in Table 2. 
Table 2. Definition of variables

\begin{tabular}{|c|c|}
\hline Variable & Definition \\
\hline \multicolumn{2}{|c|}{ Predicted variable: } \\
\hline $\mathrm{CL}=\mathrm{CL}$ & $1=$ firm received a SEO CL in year $\mathrm{t}, 0=$ otherwise \\
\hline \multicolumn{2}{|l|}{ Test variable } \\
\hline $\mathrm{CSR}=\mathrm{AKLD}$ & $\begin{array}{l}\text { Total strengths minus total concerns in social } \\
\text { responsibility dimensions including community, employee } \\
\text { relations, diversity, environment and product quality }\end{array}$ \\
\hline \multicolumn{2}{|c|}{ Moderator variables: } \\
\hline E_IA & $\begin{array}{l}\text { Environmental information asymmetry that is residual value } \\
\text { in the regression of information asymmetry on corporate } \\
\text { reporting/internal controls quality measures. The } \\
\text { information asymmetry computed exactly as in Hesarzadeh } \\
\text { (2019). Further, the corporate reporting quality/internal } \\
\text { controls measures are A_EM, R_EM, I_CW, and Rest. }\end{array}$ \\
\hline Gov & $\begin{array}{l}\text { Corporate governance quality score as constructed in } \\
\text { Lopes et al. (2016) }\end{array}$ \\
\hline \multicolumn{2}{|c|}{ Control variables: } \\
\hline A_T & Auditor tenure in years \\
\hline A_EM & $\begin{array}{l}\text { The earnings manipulations through estimates or accrual } \\
\text { computed exactly as in Dechow et al. (1995) }\end{array}$ \\
\hline Age & The number of years the firm has been listed on TSE \\
\hline B_R & $\begin{array}{l}1=\text { Altman's Z score (DeFond and Hung, 2003) is higher } \\
\text { than median, } 0=\text { otherwise }\end{array}$ \\
\hline Big & $1=$ auditor is a big audit firm, $0=$ otherwise \\
\hline C_P & $1=\mathrm{CFO}$ is an executive director, $0=$ otherwise \\
\hline Dual & $\begin{array}{l}1=\mathrm{CEO} \text { is the chairman of the board of directors, } 0= \\
\text { otherwise }\end{array}$ \\
\hline E_F & $\begin{array}{l}\text { Sum of external financing (equity }+ \text { debt) divided by total } \\
\text { assets }\end{array}$ \\
\hline Vol & $\begin{array}{l}1=\text { the volatility of daily returns for the year is in the } \\
\text { quartile four, } 0=\text { otherwise }\end{array}$ \\
\hline I_O & The percentage of shares owned by institutional investors \\
\hline L_R & $\begin{array}{l}1=\text { firm is in a litigious industry computed exactly as in } \\
\text { Francis et al. (1994), } 0=\text { otherwise }\end{array}$ \\
\hline Loss & $1=$ operational profit is negative, $0=$ otherwise \\
\hline M_C & $\begin{array}{l}\text { Market capitalization, i.e., Ln (the number of shares } \\
\text { outstanding } \times \text { share price) }\end{array}$ \\
\hline I_CW & $\begin{array}{l}1=\text { audit reports is revealed an internal control weakness } \\
\text { in year } t, 0=\text { otherwise }\end{array}$ \\
\hline R_EM & $\begin{array}{l}\text { The real earnings manipulations through real economic } \\
\text { activities based on Cohen et al. (2008) }\end{array}$ \\
\hline Rest & $1=$ firm with restatement, $0=$ otherwise \\
\hline R_OA & Return on assets, i.e., operational profit divided by total assets \\
\hline S_G & Sales growth, i.e., change in sales from year $t-1$ to year $t$ \\
\hline Indep & The percentage of independent (non-executive) directors \\
\hline
\end{tabular}

Table above describes the measurement of variables.

\section{Empirical Findings}

\subsection{Univariate Analysis}

Table 3 displays the basic features of variables. Notable, to decrease the impact of outliers on results, observations are winsorized at the $1 \%$ of continuous distributions. As shown in table, the average of $A K L D$ is approximately 0.108 and -0.019 for two subsamples: no-CL companies $(C L=0)$ and CL companies $(C L=1)$, respectively. The statistically significant difference $(\operatorname{sig}=0.071)$ between the two subsamples suggests that CSR is likely higher for the former companies. The table further displays that the average of earnings manipulations through estimates/accruals and real economic activities ( $\left.A_{-} E M \& R_{-} E M\right)$, are somewhat lower for the first subsample relative to the second subsample; however, the difference is statistically insignificant. Further, the independent samples t test- reported in the last column - suggests that internal control weakness ( $I C W)$, the restatement of financial statements (Rest) and CËO duality (Dual) are significantly lower for no-CL companies. Additionally, the bigness of auditor (Big) and board independence (Indep) are higher for no-CL companies.

Table 3. Descriptive statistics

\begin{tabular}{|c|c|c|c|c|c|c|c|}
\hline & \multicolumn{3}{|c|}{$\mathrm{CL}=0$} & \multicolumn{3}{|c|}{$\mathrm{CL}=1$} & \multirow[b]{2}{*}{ sig } \\
\hline & Mean & Median & Std. Dev. & Mean & Median & Std. Dev. & \\
\hline AKLD & 0.108 & 0.000 & 1.345 & -0.019 & 0.000 & 1.647 & $0.071^{*}$ \\
\hline A_EM & 0.005 & 0.002 & 0.095 & 0.006 & 0.012 & 0.099 & 0.196 \\
\hline R_EM & 0.006 & -0.032 & 0.552 & 0.010 & -0.036 & 0.625 & 0.426 \\
\hline I_CW & 0.037 & 0.000 & 0.191 & 0.292 & 0.000 & 0.458 & $0.000 * * *$ \\
\hline Rest & 0.026 & 0.000 & 0.160 & 0.229 & 0.000 & 0.157 & $0.000 * * *$ \\
\hline Vol & 0.239 & 0.000 & 0.427 & 0.292 & 0.000 & 0.457 & 0.402 \\
\hline M_C & 13.386 & 13.272 & 1.878 & 13.633 & 13.383 & 1.733 & 0.250 \\
\hline Age & 21.266 & 19.000 & 11.151 & 21.955 & 21.000 & 10.414 & 0.591 \\
\hline Loss & 0.100 & 0.000 & 0.303 & 0.078 & 0.000 & 0.270 & 0.441 \\
\hline R_OA & 0.152 & 0.142 & 0.159 & 0.153 & 0.140 & 0.153 & 0.992 \\
\hline B_R & 0.495 & 0.000 & 0.500 & 0.528 & 1.000 & 0.502 & 0.515 \\
\hline S_G & 0.232 & 0.202 & 1.588 & 0.235 & 0.183 & 1.194 & 0.439 \\
\hline E_F & 0.022 & 0.000 & 0.219 & 0.023 & 0.000 & 0.073 & 0.989 \\
\hline L_R & 0.396 & 0.000 & 0.489 & 0.415 & 0.000 & 0.495 & 0.739 \\
\hline Big & 0.294 & 0.000 & 0.456 & 0.224 & 0.000 & 0.419 & $0.072 *$ \\
\hline A_T & 2.290 & 2.000 & 2.168 & 2.929 & 2.000 & 2.675 & 0.807 \\
\hline I_O & 72.796 & 81.040 & 23.891 & 72.828 & 379.980 & 21.135 & 0.991 \\
\hline Dual & 0.029 & 0.000 & 0.168 & 0.146 & 0.000 & 0.355 & $0.000 * * *$ \\
\hline C_P & 0.058 & 0.000 & 0.234 & 0.056 & 0.000 & 0.231 & 0.761 \\
\hline Indep & 0.635 & 0.600 & 0.174 & 0.557 & 0.600 & 0.187 & $0.000^{* * *}$ \\
\hline $\mathrm{N}$ & & 346 & & & 91 & & \\
\hline
\end{tabular}

Table above reports summary statistics of predicted/test/control variables. The asterisks indicate a $1 \%\left({ }^{* * *}\right), 5 \%\left({ }^{* *}\right)$, and $10 \%\left({ }^{*}\right)$ level of significance.

$A K L D=$ Total strengths - Total concerns in CSR dimensions; $A_{-} E M$ refers to the accrual earnings management computed exactly as in Dechow et al. (1995); $R_{-} E M$ refers to the real earnings management computed exactly as in Cohen et al. (2008); I_CW $=1$, if audit reports is revealed an internal control weakness in year t, $\& 0=$ otherwise; Rest $=1$, for firm with restatement, \& $0=$ otherwise; $V o l=1$, if the volatility of daily returns for the year is in the quartile four, \& $0=$ otherwise; $M C=$ Ln (Number of shares outstanding $\times$ share price); Age $=$ Number of years the ${ }^{-}$firm Ln (Number of shares outstanding $\times$ share price); Age $=$ Number of years the firm has been listed on TSE; Loss $=1$, if operational profit is negative, \& $0=$ otherwise $R \_O A=$ Operational profit/Total assets; $B \_R=1$, if Altman's Z score (DeFond and Hung, 2003) is higher than median, \& $0=$ otherwise; $S_{-} G$ is the change in sales from year $\mathrm{t}-1$ to year $\mathrm{t} ; E_{-} F=($ Equity + Debt divided)/Total assets; $L R=1$, if firm is in a 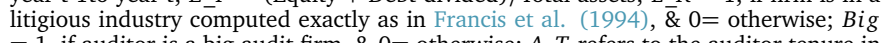 $=1$, if auditor is a big audit firm, \& $0=$ otherwise; $A_{-} T$ refers to the auditor tenure in years, $I \_O$ is the percentage of shares owned by institutional investors; Dual $=1$, if CEO is the chairman of the board of directors, \& $0=$ otherwise; $C_{-} P=1$, if CFO is an executive director, $\& 0=$ otherwise; Indep refers to the percentage of independent directors.

Table 4 tabulates the Pearson's correlations of variables. Bold indicates a $10 \%$ level of significance. As shown in the table, the correlation of $C L$ and $A K L D$ is significant and negative (-0.089), representing that CSR probably decreases CL. In general, the correlations are lesser than $50 \%$, and therefore, empirical findings are relatively free from multicollinearity problems.

\subsection{Multivariate Analysis}

\subsubsection{Test of $\mathrm{H} 1$}

Current study begins its multivariate analysis by testing the hypothesis $\mathrm{H} 1$. The hypothesis predicts that CSR is inversely associated with CL. Table 5 shows related empirical findings. The findings represent that the relationship between $A K L D$ and $C L$ is statistically significant $(\operatorname{sig}=0.036)$. Further, this association is negative $(-0.432)$, suggesting that the higher $A K L D$ leads to less CL. Hence, consistent with hypothesis $\mathrm{H} 1$, firms having more CSR are less likely to receive a CL. 
Table 4. Pearson correlation

\begin{tabular}{|c|c|c|c|c|c|c|c|c|c|c|c|c|c|c|c|c|c|c|c|c|c|c|}
\hline & AKLD & A_EM & R_EM & I_CW & Rest & Vol & M_C & Age & Loss & R_OA & B_R & S_G & E_F & L_R & Big & A_T & I_O & Dual & C_P & Indep & E_IA & Gov \\
\hline$\overline{\mathrm{CL}}$ & -0.089 & $-\overline{0} .062$ & $\overline{0} 038$ & $\overline{0.365}$ & 0.400 & 0.040 & $0 . \overline{055}$ & 0.026 & -0.037 & 0.001 & 0.031 & -0.037 & -0.001 & 0.016 & -0.065 & 0.012 & 0.001 & 0.223 & -0.015 & -0.185 & 0.016 & 0.327 \\
\hline AKLD & 1 & -0.084 & 0.003 & 0.031 & -0.034 & 0.038 & 0.065 & 0.061 & -0.080 & 0.099 & -0.068 & 0.000 & -0.012 & 0.121 & 0.004 & -0.071 & 0.008 & 0.041 & 0.023 & -0.041 & -0.081 & 0.117 \\
\hline A_EM & & 1 & -0.088 & 0.015 & -0.104 & -0.009 & 0.150 & 0.015 & -0.489 & 0.433 & -0.242 & -0.071 & -0.052 & 0.025 & 0.024 & 0.051 & 0.092 & -0.006 & 0.014 & 0.023 & 0.092 & -0.210 \\
\hline R_EM & & & 1 & -0.017 & 0.060 & 0.061 & -0.179 & 0.086 & 0.142 & -0.205 & 0.043 & -0.095 & 0.077 & 0.004 & -0.037 & -0.001 & -0.169 & -0.059 & -0.001 & -0.097 & 0.115 & -0.106 \\
\hline I_CW & & & & 1 & 0.165 & 0.017 & 0.008 & -0.072 & 0.028 & -0.024 & 0.043 & 0.018 & -0.013 & -0.034 & 0.016 & 0.033 & 0.037 & 0.132 & 0.017 & -0.062 & 0.067 & 0.397 \\
\hline Rest & & & & & 1 & -0.040 & 0.038 & 0.021 & 0.069 & -0.052 & -0.005 & 0.012 & -0.005 & 0.026 & 0.019 & 0.015 & -0.023 & 0.074 & -0.042 & -0.115 & 0.061 & 0.077 \\
\hline Vol & & & & & & 1 & -0.015 & 0.131 & 0.074 & -0.082 & 0.086 & -0.028 & 0.040 & 0.006 & 0.136 & 0.075 & 0.012 & -0.001 & 0.004 & 0.043 & 0.218 & -0.052 \\
\hline M_C & & & & & & & 1 & -0.166 & -0.197 & 0.244 & -0.082 & -0.228 & -0.054 & 0.046 & 0.038 & 0.155 & 0.143 & 0.145 & -0.031 & -0.031 & -0.261 & 0.064 \\
\hline Age & & & & & & & & 1 & 0.054 & 0.008 & 0.012 & 0.022 & 0.001 & 0.171 & 0.086 & -0.018 & -0.108 & -0.045 & 0.080 & 0.116 & 0.004 & 0.132 \\
\hline Loss & & & & & & & & & & -0.418 & 0.218 & 0.054 & 0.005 & -0.078 & 0.019 & -0.005 & -0.116 & -0.046 & -0.021 & -0.064 & 0.057 & 0.005 \\
\hline R_OA & & & & & & & & & & 1 & -0.562 & -0.051 & -0.319 & 0.234 & 0.040 & -0.017 & 0.069 & 0.028 & -0.040 & 0.070 & 0.054 & 0.019 \\
\hline B_R & & & & & & & & & & & 1 & -0.098 & 0.040 & -0.258 & 0.087 & 0.044 & 0.079 & -0.024 & 0.157 & -0.064 & 0.019 & 0.043 \\
\hline S_G & & & & & & & & & & & & 1 & 0.018 & 0.026 & 0.020 & -0.087 & -0.059 & -0.051 & -0.025 & 0.093 & 0.096 & 0.068 \\
\hline E_F & & & & & & & & & & & & & 1 & 0.032 & 0.052 & 0.057 & -0.045 & 0.020 & -0.024 & -0.019 & -0.143 & 0.094 \\
\hline L_R & & & & & & & & & & & & & & 1 & 0.056 & -0.121 & -0.178 & 0.007 & -0.062 & 0.037 & 0.003 & -0.045 \\
\hline$\overline{\mathrm{Big}}$ & & & & & & & & & & & & & & & & 0.502 & 0.028 & -0.082 & -0.053 & 0.057 & 0.062 & 0.134 \\
\hline A_T & & & & & & & & & & & & & & & & 1 & 0.012 & -0.031 & -0.024 & -0.008 & -0.023 & 0.052 \\
\hline I_ $\bar{O}$ & & & & & & & & & & & & & & & & & 1 & 0.080 & 0.070 & -0.061 & -.0154 & 0.342 \\
\hline Dual & & & & & & & & & & & & & & & & & & 1 & -0.020 & -0.095 & 0.003 & 0.031 \\
\hline C_P & & & & & & & & & & & & & & & & & & & 1 & 0.090 & 0.073 & 0.009 \\
\hline E_IA & & & & & & & & & & & & & & & & & & & & & 1 & 0.048 \\
\hline Gov & & & & & & & & & & & & & & & & & & & & & & 1 \\
\hline
\end{tabular}

Table above tabulates Pearson correlations between variables. Bold values show correlations that, statistically, are different from zero at the $10 \%$.

$C L=1$ if firm received a SEO CL in year t, \& $0=$ otherwise; $A K L D=$ Total strengths - Total concerns in CSR dimensions ; $A_{-} E M$ refers to the accrual earnings management computed exactly as in Dechow et al. (1995); $R \_E M$ refers to the real earnings management computed exactly as in Cohen et al. (2008); $I_{-} C W=1$, if audit reports is revealed an internal control weakness in year $\mathrm{t}, \& 0=$ otherwise; Rest $=1$, for firm with restatement, \& $0=$ otherwise; $V o l=1$, if the volatility of daily returns for the year is in the quartile four, \& $0=$ otherwise; $M C=$ Ln (Number of shares outstanding $\times$ share price); Age is the number of years the firm has been listed on TSE; Loss = 1, if operational profit is negative, \& $0=$ otherwise; $R O A=$ operational profit / total assets; $B R=1$, if Altman's Z score (DeFond and Hung, 2003) is higher than median, \& $0=$ otherwise; $S G$ is the change in sales from year t-1 to year t; $E F=$ (Equity + Debt divided)/Total assets; $L R=1$, if firm is in a litigious industry computed exactly as in Francis et al. (199 $\overline{4}$ ), \& $0=$ otherwise; $B i g=1$, if auditor is a big audit firm \& $0=0$ ofter otherwise; $B i g=1$, if auditor is a big audit firm, \& $0=$ otherwise; $A-T$ refers to the auditor tenure in years, $I-O$ is the percentage of shares owned by institutional investors; Dual
$=1$, if CEO is the chairman of the board of directors, \& $0=$ otherwise; $C P=1$, if CFO is an executive director, \& $0=$ otherwise; Indep refers to the percentage of independent directors.

Table 5. Impact of CSR on CL

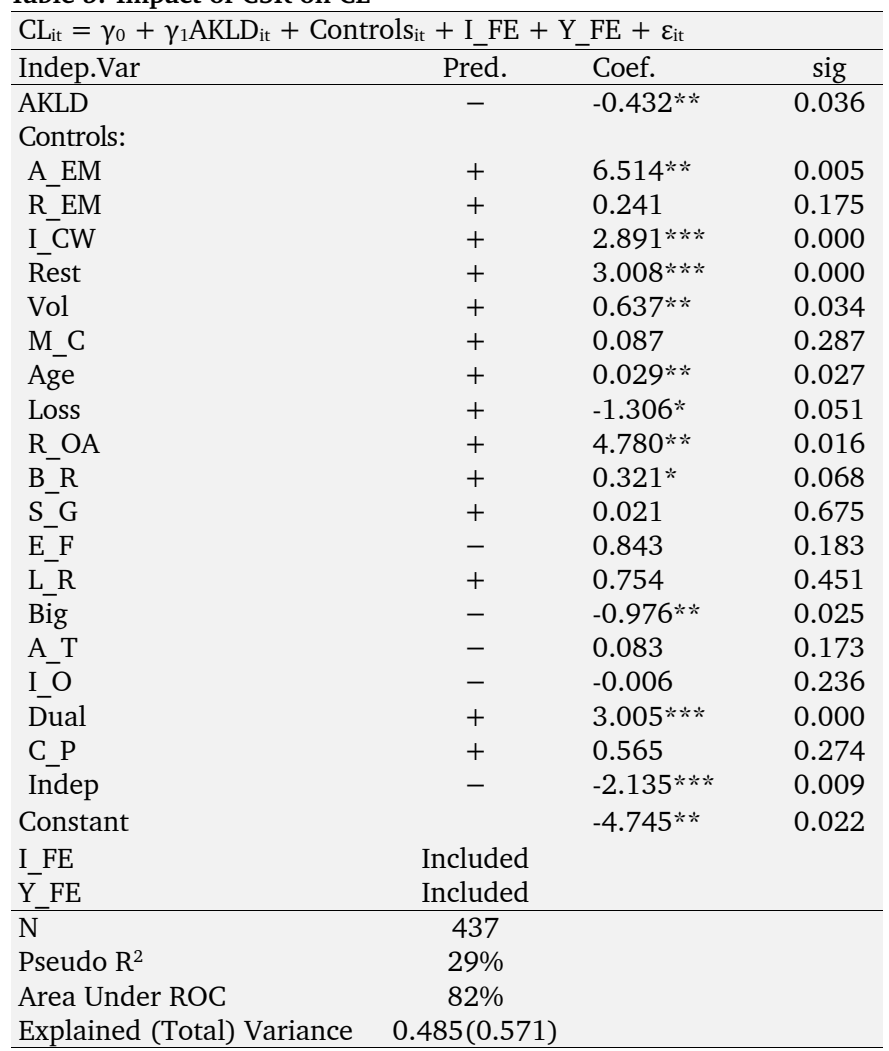

Table above displays the logistic estimation of CL $(C L)$ on CSR (AKLD). The asterisks indicate a $1 \%\left({ }^{* * *}\right), 5 \%\left({ }^{* *}\right)$, and $10 \%\left({ }^{* *}\right)$ level of significance.

$C L=1$ if firm received a SEO CL in year $\mathrm{t}, \& 0=$ otherwise; $A K L D=$ Total strengths - Total concerns in CSR dimensions; $A_{-} E M$ refers to the accrual earnings management computed exactly as in Dechow et al. (1995); $R_{-} E M$ refers to the real earnings management computed exactly as in Cohen et al. (2008); $I \_C W=1$, if audit reports is revealed an internal control weakness in year $\mathrm{t}, \& 0=$ otherwise; Rest $=1$, for firm with restatement, \& $0=$ otherwise; $V o l=1$, if the volatility of daily returns for firm with restatement, $\& 0=$ otherwise; $V o l=1$, if the volatility of daily returns
for the year is in the quartile four, \& $0=$ otherwise; $M C=$ Ln (Number of shares for the year is in the quartile four, $\& 0=$ otherwise; $M-C=L n$ (Number of shares
outstanding $\times$ share price); Age is the number of years the firm has been listed on outstanding $\times$ share price); Age is the number of years the firm has been listed on
TSE; Loss $=1$, if operational profit is negative, \& $0=$ otherwise; $R \_O A=$ operational profit / total assets; $B R=1$, if Altman's Z score (DeFond and Hung, 2003) is higher than median, \& $0=$ otherwise; $S_{-} G$ is the change in sales from year $\mathrm{t}-1$ to year $\mathrm{t} ; E_{-} F$

$=$ (Equity + Debt divided) $/$ Total assets; $L R=1$, if firm is in a litigious industry computed exactly as in Fren) audit firm, \& $0=$ otherwise; $A$ T $T$ refers to the auditor tenure in years, $I_{-} O$ is the peraudit firm, $\& 0=$ otherwise; $A-T$ refers to the auditor tenure in years, $I-O$ is the per-
centage of shares owned by institutional investors; Dual $=1$, if CEO is the chairman of the board of directors, \& $0=$ otherwise; $C_{-} P=1$, if CFO is an executive director, \& $0=$ otherwise; Indep refers to the percentage of independent directors; I_FE and Y_FE $=$ Industry and Year fixed effects.

Evidence shows that, comparable to literature (e.g., Cassell et al., 2013; Hesarzadeh and Rajabalizadeh, 2020), accrual earnings manipulation $\left(A_{-} E M\right.$; sig $\left.=0.005\right)$, internal control weakness $\left(I_{-} C W\right.$; sig $\left.=\overline{0} .000\right)$, and the restatement (Rest; sig $=0.000)^{-}$significantly affect $C L$. Therefore, generally reporting/internal control quality affects the CL. The evidence further shows that some firm features, such as stock returns volatility ( $\mathrm{Vol}$; sig $=0.034)$, age $($ Age; sig $=0.027)$, loss (Loss; sig $=0.051)$, return on assets $\left(R \_O A ;\right.$ sig $\left.=0.016\right)$ and bankruptcy rank $(B R$; sig $=0.068)$ influence $C L$. In addition, the evidence displays that firms having auditors with bigger size (Big; sig $=0.025$ ) experience a lower probability of the receipt of a CL. The CEO duality (Dual; sig $=0.000$ ) and board independence (Indep; sig $=0.009$ ) have a significant association to $C L$, collectively suggesting that strong corporate governance decreases $C L$. The results are comparable to the findings of Cassell et al. (2013) who suggest that corporate reporting/internal control quality, corporate features and corporate governance affect CL.

\subsubsection{Test of $\mathrm{H} 2$}

Consistent with $\mathrm{H} 2$, current paper predicts that environmental information asymmetry strengthens the association of CSR and CL. Table 6 reports the empirical evidence. The evidence displays the coefficient of " $A K L D \times E_{-} I A$ " which is significant ( $\operatorname{sig}=0.033)$ and negative $(-0.191)$ showing that when the environmental information asymmetry is higher, the association of $C L$ and $A K L D$ is stronger. Thus, higher environmental information asymmetry leads to a stronger association of CL and CSR. This result suggests that when the 
environmental information asymmetry is high, reviewers pay more attention to CSR. This point is probably well compatible with results obtained from literature (Su et al., 2014) suggesting that the usefulness of CSR is greater in the poor information diffusion condition.

Table 6. Impact of environmental information asymmetry on the association of CSR and CL

\begin{tabular}{|c|c|c|c|}
\hline \multicolumn{4}{|c|}{$\begin{aligned} \mathrm{CL}_{\mathrm{it}}=\gamma_{0}+\gamma_{1} \mathrm{AKLD}_{\mathrm{it}}+\gamma_{21}\left(\mathrm{E}_{-} \mathrm{IA}\right)_{\mathrm{it}}+\gamma_{22}(\mathrm{AKLD})_{\mathrm{it}} \times\left(\mathrm{E}_{-} \mathrm{IA}\right)_{\mathrm{it}} \\
+ \text { Controls }_{\mathrm{it}}+\mathrm{I}_{-} \mathrm{FE}+\mathrm{Y}_{-} \mathrm{FE}+\varepsilon_{\mathrm{it}}\end{aligned}$} \\
\hline Indep.Var & Pred. & Coef. & sig \\
\hline AKLD & - & $-0.349 * *$ & 0.049 \\
\hline E_IA & ? & $-1.587 * *$ & 0.038 \\
\hline$A \bar{K} L D \times E_{-}$IA & ? & $-0.191^{* *}$ & 0.033 \\
\hline Controls & \multicolumn{3}{|c|}{ Included } \\
\hline Constant & \multicolumn{3}{|c|}{ Included } \\
\hline I_FE & \multicolumn{3}{|c|}{ Included } \\
\hline Y_FE & \multicolumn{3}{|c|}{ Included } \\
\hline $\mathrm{N}$ & \multicolumn{3}{|l|}{437} \\
\hline Pseudo $\mathrm{R}^{2}$ & \multicolumn{3}{|l|}{$28 \%$} \\
\hline Area Under ROC & \multicolumn{3}{|l|}{$84 \%$} \\
\hline Explained (Total) Variance & \multicolumn{3}{|c|}{$0.491(0.571)$} \\
\hline
\end{tabular}

Table above displays the logistic estimation of CL $(C L)$ on the interaction of CSR and environmental information asymmetry $(A K L D \times E I A)$. The asterisks indicate a $1 \%$ $\left({ }^{* * *}\right), 5 \%\left({ }^{* *}\right)$, and $10 \%\left({ }^{*}\right)$ level of significance.

$C L=1$ if firm received a SEO CL in year $\mathrm{t}, \& 0=$ otherwise; $A K L D=$ Total strengths - Total concerns in CSR dimensions; E_IA refers to the environmental information asymmetry that is residual value in the regression of information asymmetry on corporate reporting/internal controls quality measures; Controls refer to the control variables, which are defined in Table 2; I FE and Y FE = Industry and Year fixed effects.

\subsubsection{Test of $\mathrm{H} 3$}

Consistent with $\mathrm{H} 3$, this study expects that corporate governance quality strengthens the association of CSR and CL. Table 7 provides the empirical evidence. The evidence shows that the association of " $A K L D \times G o v$ " is significant (sig= 0.046) and negative (-0.097), representing that higher corporate governance quality reinforce the association of $C L$ and $A K L D$. Thus, higher corporate governance quality leads to a stronger association of CL and CSR. This result reveals that under high corporate governance quality, reviewers pay more attention to CSR.

Table 7. Impact of corporate governance quality on the association of CSR and CL

\begin{tabular}{|c|c|c|c|}
\hline \multicolumn{4}{|c|}{$\begin{aligned} \mathrm{CL}_{\mathrm{it}}=\gamma_{0}+\gamma_{1} \mathrm{AKLD}_{\mathrm{it}}+ & \gamma_{21} \mathrm{Gov}_{\mathrm{it}}+\gamma_{22} \mathrm{AKLD}_{\mathrm{it}} \times \mathrm{Gov}_{\mathrm{it}}+\text { Controls }_{\mathrm{it}} \\
& + \text { I_FE }+ \text { Y_FE }+\varepsilon_{\mathrm{it}}\end{aligned}$} \\
\hline Indep.Var & Pred. & Coef. & $\operatorname{sig}$ \\
\hline AKLD & - & $-0.395 * *$ & 0.041 \\
\hline Gov & ? & $-0.682 * *$ & 0.038 \\
\hline AKLD $\times$ Gov & ? & $-0.097 * *$ & 0.046 \\
\hline Controls & Included & & \\
\hline Constant & Included & & \\
\hline I_FE & Included & & \\
\hline Y_FE & Included & & \\
\hline $\mathrm{N}$ & 437 & & \\
\hline Pseudo $\mathrm{R}^{2}$ & $30 \%$ & & \\
\hline Area Under ROC & $88 \%$ & & \\
\hline Explained (Total) Variance & $0.441(0.571)$ & & \\
\hline
\end{tabular}

Table above displays the logistic estimation of CL $(C L)$ on the interaction of CSR and corporate governance quality $(A K L D \times G o v)$. The asterisks indicate a $1 \%\left({ }^{* * *}\right), 5 \%$ $\left({ }^{* *}\right)$, and $10 \%\left({ }^{*}\right)$ level of significance.

$C L=1$ if firm received a SEO CL in year $\mathrm{t}, \& 0=$ otherwise; $A K L D=$ Total strengths - Total concerns in CSR dimensions; Gov refers to the corporate governance
quality score as constructed in Lopes et al. (2016); Controls refer to the control variables, which are defined in Table 2; I_FE and Y_FE = Industry and Year fixed effects.

\subsection{Supplemental Analysis}

4.3.1. The Impact of Corporate Social Responsibility on the Association of Managerial Misbehavior and Comment Letter

In this section, current paper investigates this important ethical question: do the companies engaging in managerial misconduct - such as earnings manipulation - can mislead the CL procedure by displaying more CSR? Theoretically, information recipients (here, reviewers) may unintentionally employ their affective/emotional feedbacks to CSR to estimate different metrics - such as managerial performance or fundamental value (Sen \& Bhattacharya, 2001; Frijda, 2008; Isbell et al., 2013) — as imagery-provoking nature or valueladen nature of CSR can cause positive or negative affective reactions in information recipients (e.g., Klein \& Dawar, 2004). These affective reactions unintentionally influence the individuals' subsequent judgments and weaken the information recipients' ability to react to information in the way that they intend (Elliott et al., 2014). Particularly, the affective reactions weaken the reviewers' ability to react to information in the scrutiny of managerial actions/behavior in the way that reviewers intend. Thus, it is expected that CSR weakens the relationship between managerial misbehavior and CL.

To empirically examine the aforementioned question, this study assesses the association of "CL" and "interaction of earnings manipulation and CSR". The study measures accrual earnings manipulation ( $A E M)$ following Dechow et al. (1995), and real earnings manipulation ( $\left.R_{-} E M\right)$ following Cohen et al. (2008).

Table 8 offers the empirical evidence. Briefly, the evidence indicates that the coefficients on " $A_{-} E M \times A K L D_{\text {dummy }}$ " and " $R \_E M \times A K L D_{\text {dummy }}$ " are not significant (sig=0.673 and 0.430 , respectively), suggesting that more CSR does not affect the relationship between CL and earnings manipulation. Thus, more CSR cannot cause less CL for managerial misconduct. This result, together with the separate significant impacts of CSR and earnings manipulation on CL, suggests that reviewers often see (do not see) more CSR as a complementary (substitute) heuristic cue for their scrutiny. Further, this result may be derived by "attribution perspective" in psychology, in the sense that if information recipients attribute their affect to its main cause, the affect cannot impress subsequent judgments (e.g., Schwarz \& Clore, 1983).

\subsubsection{The Spillover Effect of Corporate Social Responsibility on Comment Letter}

Theoretically, the quality and quantity of publicly relevant information including information from "peer firms" (related firms) affect the decisions of a firm's information users (Lambert et al., 2007; Ma, 2017). This is particularly because the information of the aforementioned firms is useful to information users in assessing and comparing information among firms (Pandit et al., 2011). For example, when CSR of a firm is more than CSR of its peer firms, this more CSR of the firm may offer a positive heuristic cue for reviewers and therefore, the firm experiences lower scrutiny. Thus, peer firms' CSR is theoretically expected to affect a firm's CL. Following studies (Ma, 2017; Brown et al., 2018), current paper calls this indirect outcome as "spillover effect." To provide some empirical evidence regarding this effect, this study develops and includes $A K L D^{\text {rf }}$, a peer firms' $A K L D$, in the regression of CL on CSR. the study defines the $A K L D^{\text {rf: Leader/Rival }}$ as AKLD of 'Leader'/'Rival'. Following Brown et al. (2018), this study defines the 'Leader' ('Rival') as companies with greater 
Table 8. Impact of CSR on the association of managerial misbehavior and CL

\begin{tabular}{|c|c|c|c|}
\hline \multicolumn{4}{|c|}{  } \\
\hline Indep.Var & Pred. & Coef. & sig \\
\hline$A K L D_{\text {dummy }}$ & - & $-0.542 * *$ & 0.025 \\
\hline$A \_E M$ & + & $6.975 * *$ & 0.001 \\
\hline $\bar{R} E M$ & + & $0.389 *$ & 0.065 \\
\hline$A_{-} E M \times A K L D_{\text {dummy }}$ & ? & 3.543 & 0.673 \\
\hline$R \_E M \times A K L D_{\text {dummy }}$ & ? & -0.109 & 0.430 \\
\hline Controls & \multicolumn{3}{|l|}{ Included } \\
\hline Constant & \multicolumn{3}{|l|}{ Included } \\
\hline I_FE & \multicolumn{3}{|l|}{ Included } \\
\hline Y_FE & \multicolumn{3}{|l|}{ Included } \\
\hline $\mathrm{N}$ & \multicolumn{3}{|l|}{437} \\
\hline Pseudo $\mathrm{R}^{2}$ & \multicolumn{3}{|l|}{$30 \%$} \\
\hline Area Under ROC & \multicolumn{3}{|l|}{$86 \%$} \\
\hline Explained (Total) Variance & \multicolumn{3}{|l|}{$0.508(0.571)$} \\
\hline
\end{tabular}

Table above displays the logistic estimation of CL $(C L)$ on the interaction of earnings manipulation and CSR $\left(A_{-} E M \times A K L D_{\text {dummy }} \& R_{-} E M \times A K L D_{\text {dummy }}\right)$. The asterisks indicate a $1 \%\left({ }^{* * *}\right), 5 \%\left({ }^{* *}\right)$, and $10 \%\left({ }^{*}\right)$ level of significance.

$C L=1$ if firm received a SEO CL in year t, \& $0=$ otherwise; $A K L D_{\text {dummy }}=1$, if firm's $A K L D$ is greater than median, \& $0=$ otherwise; $A_{-} E M$ refers to the accrual earnings management computed exactly as in Dechow et al. (1995); $R_{-} E M$ refers to the real earnings management computed exactly as in Cohen et al. (2008); Controls refer to the control variables, which are defined in Table 2; I_FE and Y_FE = Industry and Year fixed effects.

than $20 \%$ of the market share of sales (companies having similar/closest total assets) within the same industry-year.

Table 9 displays the results. The results present the association of $A K L D^{\mathrm{rf} \text { : Leader }} / A K L D^{\mathrm{rf} \text { : Rival }}$ and $C L$. The coefficients on the both $A K L D$ s are negative significant (Coefficient $=$ $0.052 / 0.017$; sig $=0.041 / 0.056$ ) for the regression of CL on the both peer firms' $A K L D$ s. Thus, these findings show that $A K L D$ of peer firms negatively affects a firm's $C L$, suggesting the spillover effect of CSR on CL. Moreover, the results suggest that the spillover effect from leaders is relatively larger than rivals.

4.3.3. The Impact of Comment Letter on Subsequent Corporate Social Responsibility

Literature (e.g., Gupta et al., 2014; Bozanic et al., 2017; Hesarzadeh and Rajabalizadeh, 2020) highlights the diverse consequences of receiving CLs. For example, Hesarzadeh and Rajabalizadeh (2020) argue that companies enhance their disclosures after the receipt of CLs. Furthermore, companies exposed to higher litigation risk have higher conservatism in corporate reporting (e.g., Nelson \& Pritchard, 2016). As a result, this paper expects the receiving CLs and future CSR is positively associated. To investigate this conjecture, this paper estimates the regression of $A K L D$ in year $\mathrm{t}+1$, on $C L$ and the possible determinants of $A K L D$ (see for example, Siegel \& Vitaliano, 2007; Davidson et al., 2019).

Table 10 offers the empirical evidence. Briefly, the evidence indicates that the relationship between $C L$ and $A K L D$ is statistically significant ( $\mathrm{sig}=0.052)$. Further, this association is positive (0.019), suggesting that the $C L$ leads to higher $A K L D$ in subsequent years. Hence, consistent expectation, firms respond to CL by increasing CSR.

Table 10. Impact of CL on Subsequent CSR

\begin{tabular}{|c|c|c|c|}
\hline \multicolumn{4}{|c|}{ 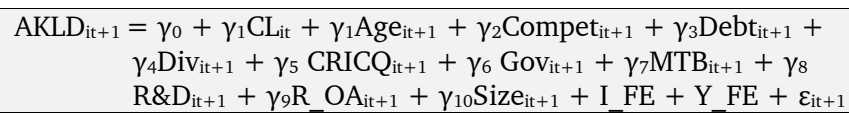 } \\
\hline Indep.Var & Pred. & Coef. & sig \\
\hline CL & + & 0.019* & 0.052 \\
\hline Age & + & 0.001 & 0.317 \\
\hline Compet & + & 0.003 & 0.479 \\
\hline Debt & - & $-0.021 *$ & 0.095 \\
\hline Div & - & $-0.084 * *$ & 0.012 \\
\hline CRICQ & - & $-0.266^{* * *}$ & 0.000 \\
\hline Gov & + & 0.315 & 0.020 \\
\hline МТВ & + & 0.012 & 0.210 \\
\hline R\&D & + & $0.147^{*}$ & 0.089 \\
\hline R_OA & + & 0.021 & 0.316 \\
\hline Size & + & $0.004^{* * *}$ & 0.000 \\
\hline Constant & \multicolumn{3}{|c|}{ Included } \\
\hline I_FE & \multicolumn{3}{|c|}{ Included } \\
\hline Y_FE & \multicolumn{3}{|c|}{ Included } \\
\hline $\mathrm{N}$ & \multicolumn{3}{|l|}{354} \\
\hline Adj. $R^{2}$ & \multicolumn{3}{|l|}{$27 \%$} \\
\hline Explained (Total) Variance & \multicolumn{3}{|c|}{$0.390(1.445)$} \\
\hline
\end{tabular}

Table above displays the OLS estimation of CSR ( $A K L D)$ on CL $(C L)$. The asterisks indicate a $1 \%\left({ }^{* * *}\right), 5 \%\left({ }^{* *}\right)$, and $10 \%\left(^{*}\right)$ level of significance.

$A K L D=$ Total strengths - Total concerns in CSR dimensions; $C L=1$, if firm received a SEO CL in year $\mathrm{t}, \& 0=$ otherwise. Age $=$ number of years the firm has been listed on TSE; Compet refers to Herfindhal-Hirschman index (market share of sales for each firm among all firms within the same industry-year); Debt $=$ Total sales for each firm among all firms within the same industry-year); Debt $=$ Total
debt/Total assets; Div = Dividend/Total assets; CRICQ is the aggregation of corporate repotting/internal control quality metrics; Gov refers to the corporate governance quality score as constructed in Lopes et al. (2016); $M T B=$ (market value of equity + total liabilities)/total assets; $R \& D=$ Research and development expense / total assets; $R O A=$ Operational profit/total assets; Size Ln(total assets). I FE and Y FE = Industry and Year fixed effects.

Table 9. Spillover effect of CSR

(1) $C_{\text {it }}=\gamma_{0}+\gamma_{1}$ AKLD $_{\text {it }}+\gamma_{21}\left(\text { AKLD }^{\text {rf: Learder }}\right)_{\text {it }}+\gamma_{22}\left(\text { AKLD }^{\text {rf: Rival }}\right)_{\text {it }}+$ Controlsit $_{i}+$ I_FE $_{-}+$Y_FE $+\varepsilon_{\text {it }}$

(2) $\mathrm{CL}_{\mathrm{it}}=\gamma_{0}+\gamma_{1}$ AKLD $_{\mathrm{it}}+\gamma_{21}$ (AKLD $\left.^{\text {rf: Learder }}\right)_{\mathrm{it}}+$ Controls $_{\mathrm{it}}+\mathrm{I} \mathrm{FE}+\mathrm{Y} \mathrm{FE}+\varepsilon_{\mathrm{it}}$

(3) $\mathrm{CL}_{\mathrm{it}}=\gamma_{0}+\gamma_{1} \mathrm{AKLD}_{\mathrm{it}}+\gamma_{21}\left(\mathrm{AKLD}^{\text {rf: Rival }}\right)_{\mathrm{it}}+$ Controls $_{\mathrm{it}}+\mathrm{I}_{-} \overline{\mathrm{FE}}+\mathrm{Y}_{-} \overline{\mathrm{FE}}+\varepsilon_{\mathrm{it}}$

\begin{tabular}{|c|c|c|c|c|c|c|c|c|c|}
\hline \multirow[b]{2}{*}{ Indep.Var } & \multicolumn{3}{|c|}{ Regression (1) } & \multicolumn{3}{|c|}{ Regression (2) } & \multicolumn{3}{|c|}{ Regression (3) } \\
\hline & Pred. & Coef. & sig & Pred. & Coef. & sig & Pred. & Coef. & sig \\
\hline \multirow[t]{3}{*}{ AKLD } & - & $-0.385^{* *}$ & 0.038 & - & $-0.406 * *$ & 0.027 & - & $-0.417 * *$ & 0.026 \\
\hline & - & $-0.052^{* *}$ & 0.041 & - & $-0.063 * *$ & 0.033 & & & \\
\hline & - & $-0.017 *$ & 0.056 & & & & - & $-0.014 *$ & 0.068 \\
\hline Controls & \multicolumn{3}{|l|}{ Included } & \multicolumn{3}{|l|}{ Included } & \multicolumn{3}{|c|}{ Included } \\
\hline Constant & \multicolumn{3}{|l|}{ Included } & \multicolumn{3}{|l|}{ Included } & \multicolumn{3}{|c|}{ Included } \\
\hline I_FE & \multicolumn{3}{|l|}{ Included } & \multicolumn{3}{|l|}{ Included } & \multicolumn{3}{|c|}{ Included } \\
\hline $\bar{Y}$ FE & \multicolumn{3}{|l|}{ Included } & \multicolumn{3}{|l|}{ Included } & \multicolumn{3}{|c|}{ Included } \\
\hline $\mathrm{N}$ & \multicolumn{3}{|l|}{437} & \multicolumn{3}{|l|}{437} & \multicolumn{3}{|l|}{437} \\
\hline Pseudo $\mathrm{R}^{2}$ & \multicolumn{3}{|l|}{$31 \%$} & \multicolumn{3}{|l|}{$27 \%$} & \multicolumn{3}{|l|}{$25 \%$} \\
\hline Area Under ROC & \multicolumn{3}{|l|}{$85 \%$} & \multicolumn{3}{|l|}{$81 \%$} & \multicolumn{3}{|l|}{$80 \%$} \\
\hline Explained (Total) Variance & \multicolumn{3}{|c|}{$0.496(0.571)$} & \multicolumn{3}{|c|}{$0.472(0.571)$} & \multicolumn{3}{|c|}{$0.465(0.571)$} \\
\hline
\end{tabular}

Table above displays the spillover effect of CSR $(A K L D)$. The table shows the logistic estimation of $A K L D^{r f}$ - including Leaders' $A K L D / R i v a l s ' A K L D$ - on CL (CL). The asterisks indicate a $1 \%\left({ }^{(* *}\right), 5 \%\left({ }^{* *}\right)$, and $10 \%\left({ }^{*}\right)$ level of significance.

$C L=1$ if firm received a SEO CL in year t, \& $0=$ otherwise $A K L D=$ Total strengths - Total concerns in CSR dimensions; $A K L D^{r f}$ : Learder and $A K L D^{r f}$ : Rival refer to the $A K L D$ of 'Leader' and 'Rival', respectively; Controls refer to the control variables, which are defined in Table 2; I_FE and Y_FE = Industry and Year fixed effects. 


\subsection{Additional Analysis}

\subsubsection{Endogeneity Analysis}

CSR is probably associated with other aspects that influence CL. For example, it could be expected that companies with higher overall corporate reporting probably engage in more CSR, and this higher corporate reporting quality can reduce the CL. Under this condition, the main finding of this paper, i.e., the negative impact of CSR on CL, stems from variables other than CSR itself. For this reason, the results are potentially subject to endogeneity concerns.

Table 11. Impact of CSR on CL: Correcting for the potential endogeneity of CSR

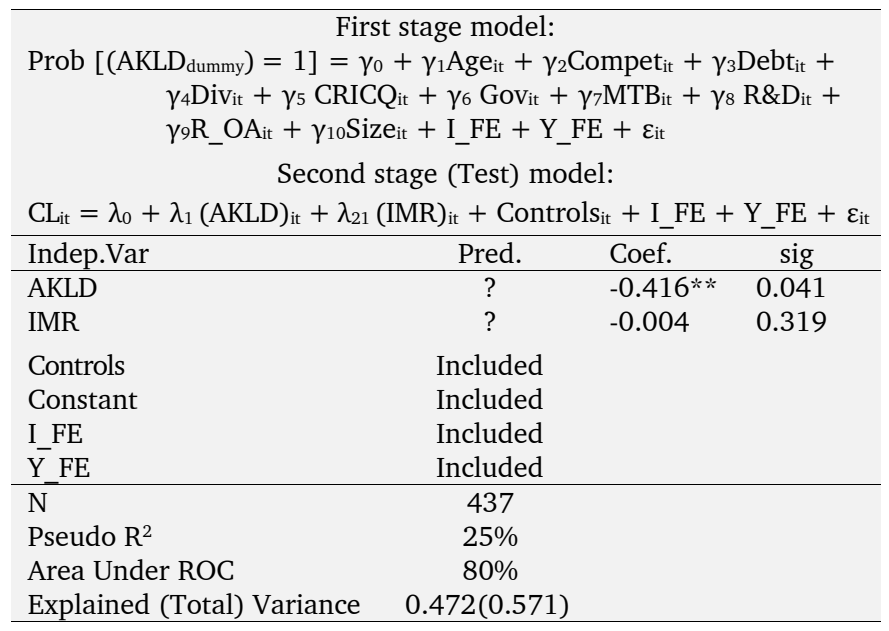

Table above displays the results concerning the association of CSR (AKLD) and CL $(C L)$, after correcting for the potential endogeneity of CSR. Specifically, the Heckman two-stage approach is used and the test model is re-estimates after adding inverse mills ratio $(I M R)$. The asterisks indicate a $1 \%\left({ }^{* * *}\right), 5 \%\left({ }^{* *}\right)$, and $10 \%\left({ }^{*}\right)$ level of significance.

$C L=1$ if firm received a SEO CL in year $\mathrm{t}, \& 0=$ otherwise $A K L D=$ Total strengths - Total concerns in CSR dimensions; $A K L D$ dummy $=1$, if firm's $A K L D$ is greater than median, \& $0=$ otherwise; Age = number of years the firm has been listed on TSE; Compet refers to the Herfindhal-Hirschman index (market share of sales for each firm among all firms within the same industry-year); Debt $=$ Total debt/Total assets; Div = Dividend/Total assets; CRICQ is the aggregation of corporate repotting/internal control quality metrics; Gov refers to the corporate governance quality score as constructed in Lopes et al. (2016); $M T B=$ (market value of equity + total liabilities)/total assets; $R \& D=$ Research and development expense / total assets; $R_{-} O A=$ Operational profit/total assets; Size Ln(total assets). I_FE and Y_FE =
Industry and Year fixed effects.
To deal with the potential endogeneity, current paper conducts Heckman's (1979) two-stage approach and reestimates the Equation (1). Specifically, in the first stage, the paper regresses CSR on the possible determinants of $A K L D$ (see for example, Siegel and Vitaliano, 2007; Davidson et al., 2019), and calculates the inverse Mills ratio (IMR) from the regression. Then, in the second stage, the paper includes the IMR in the Equation (1) as a control variable to correct for potential endogeneity. Table 11 reports the results. As is evident from the table, with the correction of endogeneity, the coefficient on $A K L D$ is -0.716 , which is still significant at the 5 percent level ( $\operatorname{sig}=0.041)$. Hence, the negative impact of CSR on CL is robust to endogeneity concerns.

\subsubsection{The Impact of Total Strengths and Concerns on Cor- porate Social Responsibility}

While CSR studies usually aggregate total strengths and total concerns for a single CSR measure, each component can represent distinct constructs (e.g., Mattingly \& Berman, 2006; Kim et al., 2012). Particularly, studies (e.g., Cho et al., 2013; Flammer, 2013; Golden et al., 2018) discuss that total strengths and total concerns should not be aggregated. Hence, current study performs further examinations by decomposing CSR (AKLD) into its two components $\left(A K L D^{+}\right.$and $A K L D^{-}$). Table 12 reports the findings.

The findings represent that the relationship between $A K L D^{+}$and $C L$ is significant ( $\left.\operatorname{sig}=0.019\right)$. This relationship is negative (-0.498), suggesting that the higher strengths lead to a lower probability of the receipt of a $C L$. Further, the relationship between $A K L D^{-}$and $C L$ is relatively significant (sig $=$ $0.056)$. This relationship is positive $(0.058)$, suggesting that the higher concerns leads to more $C L$. In addition, the relationship between $A K L D^{+}$and $C L$ is stronger than relationship between $A K L D^{-}$and $C L$. This point suggests that CL is more closely related with CSR strengths.

\subsubsection{Lag Analysis of the Relationship between Corporate Social Responsibility and Comment Letter}

As a further analysis, this paper examines whether the impact of CSR (AKLD) on CL $(C L)$ is limited to one year. In this regard, the paper re-runs the test model using $C L_{t+1} / C L_{t+2}$.

Table 12. Impact of CSR by total strengths and concerns on CL

(1) $\mathrm{CL}_{\mathrm{it}}=\gamma_{0}+\gamma_{1} \mathrm{AKLD}_{\mathrm{it}}+$ Controlsit $_{\text {it }}+\mathrm{I} \mathrm{FE}+\mathrm{Y} \mathrm{FE}+\varepsilon_{\mathrm{it}}$

(2) $\mathrm{CL}_{\mathrm{it}}=\gamma_{0}+\gamma_{1} \mathrm{AKLD}_{\mathrm{it}}{ }^{+}+$Controls $_{\mathrm{it}}+\overline{\mathrm{I}} \mathrm{FE}+\overline{\mathrm{Y}} \mathrm{FE}+\varepsilon_{\mathrm{it}}$

(3) $\mathrm{CL}_{\mathrm{it}}=\gamma_{0}+\gamma_{1} \mathrm{AKLD}_{\mathrm{it}}{ }^{-}+$Controls $_{\mathrm{it}}+\mathrm{I} \overline{\mathrm{FE}}+\mathrm{Y} \overline{\mathrm{FE}}+\varepsilon_{\mathrm{it}}$

\begin{tabular}{|c|c|c|c|c|c|c|c|c|c|}
\hline \multirow[b]{2}{*}{ Indep.Var } & \multicolumn{3}{|c|}{ Regression (1) } & \multicolumn{3}{|c|}{ Regression (2) } & \multicolumn{3}{|c|}{ Regression (3) } \\
\hline & Pred. & Coef. & sig & Pred. & Coef. & sig & Pred. & Coef. & sig \\
\hline AKLD & - & $-0.432 * *$ & 0.036 & & & & & & \\
\hline $\mathrm{AKLD}^{+}$ & & & & - & $-0.498 * *$ & 0.019 & & & \\
\hline $\mathrm{AKLD}^{-}$ & & & & & & & + & $0.058^{*}$ & 0.056 \\
\hline Controls & Included & & & Inclu & & & Incluc & & \\
\hline Constant & Included & & & Inclu & & & Incluc & & \\
\hline I FE & Included & & & Inclu & & & Incluc & & \\
\hline Y_FE & Included & & & Inclu & & & Incluc & & \\
\hline $\mathrm{N}$ & 437 & & & 437 & & & 437 & & \\
\hline Pseudo $\mathrm{R}^{2}$ & $29 \%$ & & & $32 \%$ & & & $25 \%$ & & \\
\hline Area Under ROC & $82 \%$ & & & $86 \%$ & & & $81 \%$ & & \\
\hline Explained (Total) Variance & $0.484(0$ & 71) & & 0.502 & 71) & & 0.441 & 774) & \\
\hline
\end{tabular}

Table above displays the logistic estimation of CL (CL) by strengths and concerns on CSR ( $A K L D)$. Specifically, $A K L D^{+}\left(A K L D^{-}\right)$reflects total strengths (concerns) of $C S R^{\prime} s$ five social rating categories. Notable, for further clarity, the table also re-reports the association of $A K L D$ and $C L$ (i.e., regression (1)), which is presented in the Table 5. The asterisks indicate a $1 \%\left({ }^{* * *}\right), 5 \%\left({ }^{* *}\right)$, and $10 \%\left({ }^{*}\right)$ level of significance.

$C L=1$ if firm received a SEO CL in year t, \& $0=$ otherwise; $A K L D=$ Total strengths - Total concerns in CSR dimensions; $A K L D^{+}$( $A K L D^{-}$) refers to the total strengths (concerns) in CSR dimensions; Controls refer to the control variables, which are defined in Table 2; I FE and Y FE = Industry and Year fixed effects. 
Table 13 reports the findings. The findings represent that the association of $A K L D_{t}$ and $C L_{t+1} / C L_{t+2}$ is significant (sig = 0.052 / 0.086) and negative (-0.183 / -0.054), suggesting that firms with more CSR are less likely to receive a CL on corporate reports of year $t+1 / t+2$. However, the impact of $A K L D_{t}$ on $C L_{\mathrm{t}+2}$ is significantly weaker than the impact of $A K L D_{t}$ on $C L_{\mathrm{t}+1}\left(C L_{\mathrm{t}}\right)$.

\subsubsection{Field Evidence}

To improve the robustness of causal inferences about the association of CSR and CL, this study provides evidence from interviews with SEO reviewers. Although field research suffers from problems such as small sample, the research provides an appropriate way to make sure about causal inferences that are endemic to archival research (Dichev et al., 2011). Hence, this paper conducts interviews with eight SEO reviewers. Author asks the SEO reviewers this question:
"May I ask you to describe the SEO review process and the potential factors that directly or indirectly influence the process and issuance of CLs?" Author tried to let the reviewers tell us what is important at review process.

Table 14 contains selective parts of responses. Briefly, the responses show that SEO reviewers really use heuristic cues while examining the reliability of reports. For example, Reviewer \# 1 believes that "due to...., time pressure ... we need to find some cues to efficiently and effectively select a firm for review..." Further, the results show that the voluntary and non-financial disclosures such as CSR, affects the CL. For example, Reviewer \#6 says “... social responsibility information ... are sources for our scrutiny". Thus, the responses are generally consistent with causal inferences about the significant negative association of CSR and CL.

Table 13. Impact of CSR on subsequent CLs



\begin{tabular}{|c|c|c|c|c|c|c|c|c|}
\hline \multirow[b]{2}{*}{ Indep.Var } & \multicolumn{2}{|l|}{ Regression (1) } & \multicolumn{3}{|c|}{ Regression (2) } & \multicolumn{3}{|c|}{ Regression (3) } \\
\hline & Pred. & sig & Pred. & Coef. & $\operatorname{sig}$ & Pred. & Coef. & sig \\
\hline AKLD & $-0.432 *$ & 0.036 & - & $-0.183^{*}$ & 0.052 & - & $-0.054 *$ & 0.086 \\
\hline Controls & Included & & Inclu & & & Incluc & & \\
\hline Constant & Included & & Inclu & & & Incluc & & \\
\hline I FE & Included & & Inclu & & & Incluc & & \\
\hline $\bar{Y} \_\mathrm{FE}$ & Included & & Inclu & & & Incluc & & \\
\hline $\mathrm{N}$ & 437 & & 373 & & & 312 & & \\
\hline Pseudo $\mathrm{R}^{2}$ & $29 \%$ & & $30 \%$ & & & $23 \%$ & & \\
\hline Area Under ROC & $82 \%$ & & $85 \%$ & & & $80 \%$ & & \\
\hline Explained (Total) Variance & $0.474(0.571)$ & & 0.509 & 589) & & 0.491 & $.598)$ & \\
\hline
\end{tabular}

Table above displays the logistic estimation of subsequent CL $(C L)$ on CSR ( $A K L D$ ). Notable, for further clarity, the table also re-reports the association of $A K L D$ and $C L$ (i.e., regression (1)), which is presented in the Table 5 . The asterisks indicate a $1 \%\left({ }^{* * *}\right), 5 \%\left({ }^{* *}\right)$, and $10 \%\left({ }^{*}\right)$ level of significance.

$C L=1$ if firm received a SEO CL in year t, \& $0=$ otherwise; $A K L D=$ Total strengths - Total concerns in CSR dimensions; Controls refer to the control variables, which are defined in Table 2; I FE and Y FE = Industry and Year fixed effects.

Table 14. Interviews with SEO Reviewers

\footnotetext{
Question: "May I ask you to describe the SEO review process and the potential factors that directly or indirectly influence the process and issuance of CLs?" Responses:

- Reviewer \#1: ... Clearly, it is impossible to review all or most of the reports, due to..., time pressure ...So, we need to find some cues to efficiently and effectively select a firm for review... the reviews takes a lot of time ... and therefore, reviewers will thus look at some standards as a way to save time... some of these standards and aspects are determined according to the internal instructions..... Some of them [standards] are not specified in the instructions... other factors, like psychology or behavioral aspects, are also affect the reviewers' decisions.... For example, reputation and corporate image ... responsible business... or a firm voluntary provides high quality financial and non-financial disclosures, leave a positive signal for reviewers...

- Reviewer \#2: ... reviewers do not disclose the exact criteria or analytical procedures used to select firms for their review process, .....The nature of the process is required to investigate several dimensions of financial reporting... about very general criteria...some issues such as ..... social and environmental reports may indirectly affects the decision of reviewers to select a firm for review:.since poorer information or weaker informational environmental leads to more scrutiny and more sending CLs, reasonably firms can improve their information or informational environmental to reduce scrutiny ....

- Reviewer \#3: We seek to improve a fair and complete picture of financial position and performance ...because we want to protect investors.... We often focus on mandated financial reporting; however, you know financial numbers are related to wide and different ranges of functions, like financial functions or even social and environmental functions.... So, we should address a huge range of information to control the reliability of the mandated financial reports....

- Reviewer \#4: ... The review process included a review of diverse aspects of the corporate reporting. ... Reviewers attempt to find some cues while assessing the reliability of reports... The scope of cues is relatively extensive such as ... socially responsible approach of a company ...I feel the use of them are very necessary, when we face workload compression ...

- Reviewer \#5: ....For an effective review, you should check different issues in out of formal, regulated reports, like websites, voluntary disclosures, news...the absence of information about these issues, certainly, creates incentives for you to send CLs...

- Reviewer \#6: ...We know that managers may use corporate reporting as an entrenchment mechanism. That is why we are interested to credibility and information content of reports. ..., social responsibility information ... are sources for our scrutiny..

- Reviewer \#7: ... truthfulness of disclosure is vital:. obviously, companies having poorer governance, weaker financial position ..., are reviewed and received CLs... voluntary information... of firms with managerial misbehavior is not reliable for us ...

- Reviewer \#8: ... in this process, we monitor companies with weak reporting relative to other similar firms, ...
}

Table above provides some field evidence on whether SEO reviewers address the CSR. Specifically, the table presents selective parts of responses about the scrutiny process of SEO. 


\section{Conclusion}

This paper shows that CSR negatively affects CL, suggesting that CSR decreases CL. This finding is robust to (consistent with) endogeneity analysis (field evidence). On the one hand, the finding is consistent with those studies indicating that regulators understand the importance of CSR (e.g., Albareda, 2008; Chen et al., 2015; Brooks \& Oikonomou, 2018). On the other hand, the finding is in line with literature suggesting that CSR may be an element of corporate risk management (Francis \& Armstrong, 2003; Koh et al., 2013; Bae et al., 2020) and may help companies to improve a firm's reputation (Wang \& Qian, 2011; Liu et al., 2018).

This study further shows that the association of CSR and CL is larger among firms facing higher environmental information asymmetry and firms having higher corporate governance quality. These findings are comparable to evidence suggesting that the beneficial effect of corporate reporting is moderated by environmental information asymmetry and corporate governance quality (Bushman et al., 2011; Khan et al., 2012; Su et al., 2014; Cheng \& Wu, 2014; Cao et al., 2019). Furthermore, the empirical findings reveal the spillover effect of CSR, in the sense that more CSR of peer firms increases a firm's CL.

Generally, this is the first study that performs empirical tests on the relation between CSR and CL. Particularly, this study makes several important contributions. First, the study enriches the literature on the consequences of CSR (e.g., Dhaliwal et al., 2011; Brooks \& Oikonomou, 2018; LópezGonzález et al., 2019; Tomas Siueia \& Wang, 2019). In this regard, the results of this study highlight a new benefit of CSR (i.e., the reduction in CLs), and therefore, contribute to resolving a long-standing debate in CSR studies over whether or not companies should divert their scarce resources to improving their CSR. In addition, this study extends the current literature by presenting evidence on how the consequences of CSR may be reinforced. These contributions are important, especially for emerging markets. This is because, understanding the consequences of CSR in emerging markets and knowing the moderating factors which affect the consequences of CSR are very important. To clarify, firstly, in capital markets with poor institutional setting such as emerging markets, information resources are limited and it is relatively hard to communicate with information recipients about a company (Su et al., 2014). In this respect, CSR is an appropriate solution for companies to mitigate the problem (Levy \& Kaplan, 2009). Secondly, CSR-related activities are considered critical in enabling emerging markets to foster economic development and social equity (Nair et al., 2019). Thirdly, there is a significant pressure by socially responsible investors and other stakeholders in emerging markets to adopt a businessmodel approach to CSR that links CSR to firm value creation (Narwal \& Singh, 2013). Fourthly, there is a significant growth in the listing of local companies on international stock exchanges (Jackling \& Johl, 2009) which emphasize on CSR. This development is accompanied by a drive to attract more foreign direct investment through developing CSR activities (Nair et al., 2019).

Second, this study extends the stream of research has formed to explore the determinants of public enforcement. Particularly, the study enriches the emerging literature (e.g., Robinson et al., 2011; Cassell et al., 2013; Johnston \& Petacchi, 2017) on the determinants of receiving CLs by introducing a new factor (i.e., CSR) that reduces CLs. In addition, this paper to validate the causal inferences about the association of CSR and CL, for the first time, provides field evidence from interviews with regulatory reviewers. This is closely consistent with Rajgopal's (2019) call for better "integrating practice into accounting research" and providing "believable" findings from practitioners' perspectives.

Third, the study extends the study of Kim et al. (2012) on the association between CSR and earnings management (as captured by discretionary accruals, real operating activities, and Accounting and Auditing Enforcement Releases, namely AAER). Because: firstly, while the theoretical and empirical discussions in Kim et al.'s study focus on the relationship between CSR and earnings management, current study focuses on the relationship between CSR and CL. Secondly, although they and this paper use the releases of a securities commission, mainly AAER differs from CL, as the securities commissions issue (send) an AAER (a CL) if they find a fraudulent reporting (potential deficiency). For this reason, AAER (CL) is often used in accounting literature as a proxy for financial reporting misstatement (regulatory scrutiny) (see for example, Kim et al., 2012; Krishnan et al., 2018; Frankel \& Yan Sun, 2018; versus Do \& Zhang, 2018; Cazier et al., 2018; Naughton et al., 2018). Thirdly, while current paper conducts its study in a developing capital market, they conduct their research in the largest developed capital market, i.e., U.S capital market. In this regard, since the institutional setting of developed capital markets is different from that of developing capital markets in ways that affect the efficacy of CSR (Mohammad \& Husted, 2019), we cannot easily speak to the generalizability of Kim et al.'s results outside of the developed capital markets. Finally, for the first time, the current study provides empirical evidence on the spillover effect of CSR in the context of CL.

The findings of this paper are of primary interest to managers and stockholders involved in the CL procedure. For example, (1) the findings offer a practical way, that is, increased CSR, to alleviate a significant risk (i.e., CL) faced by firms. In this regard, the findings show that this practical way may not be opportunistic, because more CSR does not influence the association of managerial misbehavior and CL. (2) The findings suggest how the aforementioned practical way may be more effective. In this regard, findings show that under higher environmental information asymmetry and higher corporate governance quality, the way is more effective. Regardless, the findings display the CSR as a significant determinant of CL that should be useful for academics who are looking for way to explain or model the securities commissions' behavior/decision. Further, the findings raise a host of possible directions for future studies by highlighting the externalities of CSR in the capital market. Additionally, the findings should be useful for other stakeholders, such as financial analysts or external auditors, who like to evaluate different types of risks around companies, including regulatory risks.

This paper notes readers to exercise some caution while employing the results. This is because, firstly, in this research, sample includes firms listed on the TSE, that is, a less developed capital market. As mentioned by Su et al. (2014), in more developed capital markets, where more information is available, information users may assess the firms from diverse channels, and therefore, the relaying on signaling effect of CSR may be lower. As a result, the effect of CSR on CL may be less strong in more developed capital markets. Secondly, it is possible that the measure of CSR does not include all CSR information, such as those included in unknown websites, and therefore, it may bias against empirical findings. Thirdly, the measure of regulatory CL in this research may not reflect all of regulatory CL. As such, the effect of CSR on regulatory CL may be different for other regulatory CL. Fourthly, 
while this paper employs the Heckman two-stage approach to correct for the potential endogeneity, to the extent that this approach is not exhaustive, one should be cautious in drawing causal inferences.

Finally, current study encourages future research to a further examination of different institutional contexts, as there are some major differences of managers' orientation across countries. For clarity, while in Anglo-Saxon countries, managers are more sensitive to satisfying the interests of stockholders, in Continental countries, managers are more inclined to the improvement of interaction with suppliers and banks (Surroca \& Tribó, 2008). The study further encourages future research to use content and textual analysis in examining how CSR affects content, tone, and language of CLs. In addition, this study encourages future research to examine other important factors that may affect the relationship between the CSR and CL, such as the personality of mangers like managerial materialism-defined as "relatively high luxury asset ownership" (Davidson et al., 2019) —, or the characteristics of firms like political connections (Muttakin et al., 2018) and types of ownership (López-González et al., 2019). This is because these factors may provide a different signal for regulatory reviewers about the strategy and reliability of a firm's CSR. For example, Davidson et al. (2019) discuss that the materialistic managers have lesser concern for others, and are less sensitive to how their actions affect the community and environment. Muttakin et al. (2018) suggest that the perceived need for CSR as a legitimation strategy diminishes for politically connected firms, and Bianchi et al. (2019) argue that in settings where the existence of political connections are viewed as damaging collective interests of stakeholders, political connected firms can deal with legitimacy issues from such connections by resorting to CSR practices and the reporting thereof. In addition, López-González et al. (2019) suggest that family firms have shown to have a singular behavior in terms of CSR, earnings management, and concern for maintaining their reputation.

\section{Funding}

This research did not receive any specific grant from funding agencies in the public, commercial or not-for-profit sectors.

\section{Conflict of interests}

The author declares no conflict of interests.

\section{References}

Albareda, L., Lozano, J. M., Tencati, A., Midttun, A., \& Perrini, F. (2008). The changing role of governments in corporate social responsibility: drivers and responses. Business Ethics: A European Review, 17(4), 347-363. https: //doi.org/10.1111/j.1467-8608.2008.00539.x

Ballestero, R., \& Schmidt, J. J. (2019). Does auditor involvement expedite SEC comment letter resolution? Available at SSRN: https://doi.org/10.2139/ssrn.3350730

Bae, J., Choi, W., \& Lim, J. (2020). Corporate social responsibility: An umbrella or a puddle on a rainy day? Evidence surrounding corporate financial misconduct. European Financial Management, 26(1), 77-117. https://doi.org/ 10.1111/eufm.12235

Baker, T., \& Griffith, S. J. (2009). How the merits matter: Dir- ectors' and officers' insurance and securities settlements. University of Pennsylvania Law Review, 157. Available at SSRN: https://ssrn.com/abstract $=1101068$

Bansal, P., \& Clelland, I. (2004). Talking trash: legitimacy, impression management, and unsystematic risk in the context of the natural environment. Academy of Management Journal, 47(1), 93-103. https://doi.org/10.2307/ 20159562

Barton, J., Kirk, M., Reppenhagen, D., \& Thayer, J. (2015). Why do socially responsible firms manage earnings? Working paper, Emory University, University of Florida, and University of Virginia.

Baugh, M., \& Schmardebeck, R. (2020). Auditor Style and Common Disclosure Deficiencies: Evidence from SEC Comment Letters. Available at SSRN: https://doi.org/10. 2139/ssrn.3368511

Bianchi, M. T., Monteiro, P., Azevedo, G., Oliveira, J., Viana, R. C., \& Branco, M. C. (2019). Political connections and corporate social responsibility reporting in Portugal. Journal of Financial Crime, 26(4), 1203-1215. https://doi.org/10.1108/jfc-10-2018-0111

Bills, K. L., Cating, R., Lin, C., \& Seidel, T. A. (2019). The spillover effect of SEC comment letters through audit firms: Evidence from subjective accounting areas. Available at SSRN: https://doi.org/10.2139/ssrn.3349191

Bonsón, E., \& Bednárová, M. (2015). CSR reporting practices of Eurozone companies. Revista de Contabilidad-Spanish Accounting Review, 18(2), 182-193. https://doi.org/10. 1016/j.rcsar.2014.06.002

Bozanic, Z., Dietrich, R., \& Johnson, B. (2017). SEC comment letters and firm disclosure. Journal of Accounting and Public Policy, 36, 337-357. https://doi.org/10.1016/ j.jaccpubpol.2017.07.004

Brooks, C., \& Oikonomou, I. (2018). The effects of environmental, social and governance disclosures and performance on firm value: A review of the literature in accounting and finance. The British Accounting Review, 50(1), 115. https://doi.org/10.1016/j.bar.2017.11.005

Brown, S. V., Shaolee Tian, X., \& Wu Tucker, J. (2018). The spillover effect of SEC comment letters on qualitative corporate disclosure: Evidence from the risk factor disclosure. Contemporary Accounting Research, 35(2), 622-656. https://doi.org/10.1111/1911-3846.12414

Burke, Q., Chen, P. C., \& Lobo, G. J. (2020). Is Corporate Social Responsibility Performance Related to Conditional Accounting Conservatism? Available at SSRN: https:// doi.org/10.2139/ssrn.3533409

Bushman, R. M., Piotroski, J. D., \& Smith, A. J. (2011). Capital allocation and timely accounting recognition of economic losses. Journal of Business Finance \& Accounting, 38(1-2), 1-33. https://doi.org/10.1111/j.1468-5957. 2010.02231.X

Cao, Z., \& Rees, B. (2019). Corporate social responsibility and earnings quality in the context of changing regulatory regimes. Available at SSRN: https://doi.org/10. 2139/ssrn.2883387

Carey, P., Liu, L., \& Qu, W. (2017). Voluntary corporate social responsibility reporting and financial statement auditing in China. Journal of Contemporary Accounting \& Economics, 13(3), 244-262. https://doi.org/10.1016/j.jcae. 2017.09.002

Cassell, C. A., Cunningham, L. M., \& Lisic, L. L. (2019). The readability of company responses to SEC comment letters and SEC 10-K filing review outcomes. Review of Accounting Studies, 24(4), 1252-1276. https://doi.org/10.1007/ 


\section{s11142-019-09507-x}

Cassell, C. A., Dreher, L. M., \& Myers, L. A. (2013). Reviewing the SEC's review process: $10-\mathrm{K}$ comment letters and the cost of remediation. The Accounting Review, 88 (6), 1875-1908. https://doi.org/10.2308/accr-50538

Cazier, R. A., McMullin, J. L., \& Treu, J. (2018). Are lengthy and boilerplate risk factor disclosures inadequate? An examination of judicial and regulatory assessments of risk factor language. Available at SSRN: https://doi.org/10. 2139/ssrn.3167611

Chen, C., Kim, J. B., Wei, M., \& Zhang, H. (2018). Linguistic information quality in customers' forward-looking disclosures and suppliers' investment decisions. Contemporary Accounting Research, 36 (3), 1751-1783. https: //doi.org/10.1111/1911-3846.12471

Chen, N. (2015). Repatriation taxes and the value of cash holdings. Working Paper, University of California at Irvine. Available at SSRN: https://ssrn.com/abstract= 2496756. https://doi.org/10.2139/ssrn.2496756

Chen, X., Harford, J., \& Li, K. (2007). Monitoring: Which institutions matter? Journal of Financial Economics, 86, 279-305. https://doi.org/10.1016/j.jfineco.2006.09. 005

Cheng, X., Gao, L., Lawrence, J. E., \& Smith, D. B. (2014). SEC division of corporation finance monitoring and CEO power. Auditing: A Journal of Practice \& Theory, 33 (1), 29-56. https://doi.org/10.2308/ajpt-50625

Cho, S. Y., Lee, C., \& Pfeiffer, R. J. (2013). Corporate social responsibility performance and information asymmetry. Journal of Accounting and Public Policy, 32(1), 71-83. https://doi.org/10.1016/j.jaccpubpol.2012.10.005

Christensen, D. M. (2016). Corporate accountability reporting and high-profile misconduct. The Accounting Review 91 (2):377-399.

Christensen, H. B., Floyd, E., Liu, L. Y., \& Maffett, M. (2017). The real effects of mandated information on social responsibility in financial reports: Evidence from minesafety records. Journal of Accounting

Cohen, D. A., Dey, A., \& Lys, T. Z. (2008). Real and accrualbased earnings management in the pre and postSarbanesOxley periods. The Accounting Review, 83 (3), 757787. https://doi.org/10.2308/accr.2008.83.3.757

Cohen, J. R., \& Simnett, R. (2015). CSR and assurance services: A research agenda. Auditing: A Journal of Practice \& Theory, 34(1), 59-74. https://doi.org/10.2308/ ajpt-50876

Cunningham, L. M., Johnson, B. A., Johnson, E. S., \& Lisic, L. L. (2020). The switchup: An examination of changes in earnings management after receiving SEC comment letters. Contemporary Accounting Research, 37(2), 917-944. https://doi.org/10.1111/1911-3846.12546

Davidson, R. H., Dey, A., \& Smith, A. J. (2019). CEO materialism and corporate social esponsibility. The Accounting Review, 94(1), 101-126. https://doi.org/10.2308/ accr-52079

Dechow, P., Sloan, R. and Sweeney, A., (1995). Detecting earnings management, The Accounting Review 70, pp. 193-225.

DeFond, M. L., \& Hung, M. (2003). An empirical analysis of analysts' cash flow forecasts. Journal of Accounting and Economics, 35(1), 73-100. doi:10.1016/ s0165-4101(02)00098-8

Deng, X., Kang, J., \& Low, B. S. (2013). Corporate social responsibility and stakeholder value maximization: Evidence from mergers. Journal of Financial Economics,
110(1), 87-109. https://doi.org/10.1016/j.jfineco.2013. 04.014

Dhaliwal, D. S., Li, O. Z., Tsang, A., \& Yang, Y. G. (2011). Voluntary nonfinancial disclosure and the cost of equity capital: The initiation of corporate social responsibility reporting. The Accounting Review, 86(1), 59-100. https: //doi.org/10.2308/accr.00000005

Dhaliwal, D. S., Radhakrishnan, S., Tsang, A., \& Yang, Y. G. (2012). Nonfinancial Disclosure and Analyst Forecast Accuracy: International Evidence on Corporate Social Responsibility Disclosure. The Accounting Review, 87(3), 723-759. doi:10.2308/accr-10218

Diamond, D.W., Verrecchia R. E. (1991). Disclosure, liquidity, and the cost of capital. The Journal of Finance, 46(4), 1325-1359.

Dichev, I. D., Graham. J., Harvey. C. R., \& Rajgopal. S. (2011). Earnings quality: Evidence from the field. Journal of Accounting and Economics, 56 (2-3), 1-33. https://doi.org/10.1016/j.jacceco.2013.05.004

Do, T. (Peter), \& Zhang, H. (2018). Styles of Regulators: Evidence from the SEC's Comment Letters. Available at SSRN: https://doi.org/10.2139/ssrn.3266002

Duro, M., Heese, J., \& Ormazabal, G. (2018). The effect of enforcement transparency: Evidence from SEC commentletter reviews. Review of Accounting Studies, 24 (3), 780823. https://doi.org/10.1007/s11142-019-09503-1

El Ghoul, S., Guedhami, O., Kwok, C. C. Y., \& Mishra, D. R. (2011). Does corporate social responsibility affect the cost of capital? Journal of Banking \& Finance, 35(9), 2388-2406. https://doi.org/10.1016/j.jbankfin. 2011.02.007

Elliott, W. B., Jackson, K. E., Peecher, M. E, \& White. B. J. (2014), The unintended effect of corporate social responsibility performance on investors' estimates of fundamental value, The Accounting Review 89 (1), 275-302. https://doi.org/10.2308/accr-50577

European commission. (2014). Directive 2014/95/EU of the European parliament and of the council, Official Journal of the European Union.

Fakhari, H., Rezaei, P. Y., Noroozi, M. (2017). Corporate social responsibility disclosure and investment efficiency, Journal of Financial Management Strategy, 4(15), 85-106.

Fernbach, P. M., \& Rehder, B. (2013). Cognitive shortcuts in causal inference. Argument \& Computation, 4(1), 64-88. https://doi.org/10.1080/19462166.2012.682655

Fieseler, C. (2011). On the corporate social responsibility perceptions of equity analysts. Business Ethics: A European Review, 20(2), 131-147. https://doi.org/10. $1111 / j .1467-8608.2011 .01616 . x$

Flammer, C. (2013). Corporate social responsibility and shareholder reaction: The environmental awareness of investors. Academy of Management Journal, 56(3), 758781. https://doi.org/10.5465/amj.2011.0744

Flammer, C., \& Bansal, P. (2017). Does a long-term orientation create value? Evidence from a regression discontinuity. Strategic Management Journal, 38(9), 1827-1847. https://doi.org/10.1002/smj.2629

Francis, J., LaFond, R., Olsson, P., \& Schipper, K. (2005). The market pricing of accruals quality. Journal of Accounting and Economics, 39 (2), 295-327. https://doi.org/10. 1016/j.jacceco.2004.06.003

Francis, J., Philbrick, D., \& Schipper, K. (1994). Shareholder litigation and corporate disclosures. Journal of Accounting Research, 32 (2), 137-164. https://doi.org/10.2307/ 2491279

Francis, R., \& Armstrong, A. (2003). Ethics as a risk man- 
agement strategy: The Australian experience. Journal of Business Ethics, 45(4), 375-385. https://doi.org/10. 1023/a:1024163831371

Frankel. R. M., \& Sun. Y. (2018). Predicting accruals based on cash-flow properties. The Accounting Review, 93 (5), $165-186$

Frijda, N. (2008). The psychologists 'point of view. Handbook of emotions (3rd ed.). New York: Guilford Press.

Ghaderi, Z., Mirzapour, M., Henderson, J. C., \& Richardson, S. (2019). Corporate social responsibility and hotel performance: A view from Tehran, Iran. Tourism Management Perspectives, 29, 41-47. https://doi.org/10.1016/j. tmp.2018.10.007

Gietzmann, M. B., \& Pettinicchio, A. K. (2014). External auditor reassessment of client business risk following the issuance of a comment letter by the SEC. European Accounting Review, 23 (1), 57-85. https://doi.org/10.1080/ 09638180.2013 .774703

Gill, A. (2008). Corporate governance as social responsibility: A research agenda", Berkeley Journal of International Law. 26 (2), 452-478

Guiral, A. (2012). Corporate Social Performance, Innovation Intensity, and Financial Performance: Evidence from Lending Decisions. Behavioral Research in Accounting, 24(2), 65-85. doi:10.2308/bria-50096

Godfrey, P. C. (2005). The relationship between corporate philanthropy and shareholder wealth: A risk management perspective. Academy of Management Review, 30(4), 777-798. [https://doi.org/10.5465/amr.2005. 18378878]

Golden, J., Sun, L., \& Zhang, J. H. (2018). Corporate social responsibility and goodwill impairment. Accounting and the Public Interest, 18(1), 1-28. https://doi.org/10. 2308/apin-51971

Gupta, S., Mills, L. F., \& Towery, E. M. (2014). The effect of mandatory financial statement disclosures of tax uncertainty on tax reporting and collections: The case of FIN 48 and multistate tax avoidance. The Journal of the American Taxation Association, 36(2), 203-229. https: //doi.org/10.2308/atax-50766

Harjoto, M.A., \& Jo, H. (2015). Legal vs. normative CSR: Differential impact on analyst dispersion, stock return volatility, cost of capital, and firm value. Journal of Business Ethics, 128(1), 1-20. https://doi.org/10.1007/ s10551-014-2082-2

Healy, P. M., \& Palepu, K. G. (2001). Information asymmetry, corporate disclosure, and the capital markets: A review of the empirical disclosure literature. Journal of Accounting and Economics, 31(1-3), 405-440. https://doi.org/ 10.1016/s0165-4101(01)00018-0

Heckman, J. J. (1979). Sample Selection Bias as a Specification Error. Econometrica, 47(1), 153. doi:10.2307/ 1912352

Hesarzadeh, R. (2020). Regulatory Oversight and Managerial Ability. Eurasian Business Review, 10(4), 559-585. https://doi.org/10.1007/s40821-020-00150-0. Available at SSRN: https://ssrn.com/abstract $=3531713$

Hesarzadeh, R., \& Rajabalizadeh, J. (2020). Does securities commission oversight reduce the complexity of financial reporting?. Revista de Contabilidad-Spanish Accounting Review, 23(1), 1-17. https://doi.org/10.6018/rcsar. 389791

Hickman, L. (2018). The role of information asymmetry in CSR reporting: A comparison of publicly-traded and privately-held firms. Available at SSRN: https://doi.org/

\subsection{9/ssrn.3121275}

Hoi, C. K., Wu, Q., \& Zhang, H. (2013). Is corporate social responsibility (CSR) associated with tax avoidance? Evidence from irresponsible CSR activities. The Accounting Review, 88(6), 2025-2059. https://doi.org/10.2308/ accr-50544

Hong, H., \& Kacperczyk, M. (2009). The price of sin: The effects of social norms on markets. Journal of Financial Economics, 93(1), 15-36. https://doi.org/10.1016/j.jfineco. 2008.09.001

Hu, W., \& Fu, X. (2020). Does individual investors' online search activities reduce information asymmetry? Evidence from stock exchanges' comment letters in China. Asia-Pacific Journal of Accounting \& Economics, 1-21. https://doi.org/10.1080/16081625.2020.1754248

Isbell, L. M., Lair, E. C., \& Rovenpor, D. R. (2013). Affect-asinformation about processing styles: A cognitive malleability approach. Social and Personality Psychology Compass, 7(2), 93-114. https://doi.org/10.1111/spc3.12010

Islamic Consultative Assembly. (2005). Securities Market Act of the Islamic Republic of Iran. Available at http:// rdis.ir/RuleDetailEn.asp?RuleID $=18$

Jalili, S., \& Gheisari, F. (2013). Earnings quality and corporate social responsibility. Audit Knowledge, 14 (57), 147170. (In Persian)

Jackling, B., \& Johl, S. (2009). Board structure and firm performance: evidence from India's top companies. Corporate Governance: An International Review, 17 (4), 492-509. https://doi.org/10.1111/j.1467-8683.2009.00760.x

Jo, H., \& Na, H. (2012). Does CSR reduce firm risk? Evidence from controversial industry sectors. Journal of Business Ethics, 110(4), 441-456. https://doi.org/10.1007/ s10551-012-1492-2

Johnston, R., \& Petacchi, R. (2017). Regulatory oversight of financial reporting: Securities and Exchange Commission comment letters. Contemporary Accounting Research, 34 (2), 1128-1155. https://doi.org/10.1111/1911-3846. 12297

Kytle, B., \& Ruggie, J.G. (2005). Corporate social responsibility as risk management: a model for multinationals. Harvard University's John F. Kennedy School of Government's Corporate Social Responsibility Working paper 10, Cambridge MA

Khan, A., Muttakin, M. B., \& Siddiqui, J. (2012). Corporate governance and corporate social responsibility disclosures: Evidence from an emerging economy. Journal of Business Ethics, 114(2), 207-223. https://doi.org/10. 1007/s10551-012-1336-0

Kim, Y., Park, M. S., \& Wier, B. (2012). Is earnings quality associated with corporate social responsibility? The Accounting Review, 87(3), 761-796. https://doi.org/10. 2308/accr-10209

Klein, J., \& Dawar. N. (2004), Corporate social responsibility and consumers' attributions and brand evaluations in a product-harm crisis. International Journal of Research in Marketing, 21 (3), 203 - 217. https://doi.org/10.1016/ j.ijresmar.2003.12.003

Koh, P.-S., Qian, C., \& Wang, H. (2013). Firm litigation risk and the insurance value of corporate social performance. Strategic Management Journal, 35(10), 1464-1482. https://doi.org/10.1002/smj.2171

Kotchen, M., \& Moon, J. J. (2012). Corporate social responsibility for irresponsibility. Journal of Economic Analysis \& Policy, 12(1). https://doi.org/10.1515/1935-1682.3308

KPMG. (2015). Currents of change: The KPMG survey of corporate responsibility reporting 2015. 
https://assets.kpmg/content/dam/kpmg/pdf/2016/02/ kpmg\%2dinternational $\% 2$ dsurvey $\% 2$ dof $\% 2$ dcorporate $\%$ 2dresponsibility\%2dreporting\%2d2015.pdf

Krishnan, G., Myllymäki, E.-R., \& Nagar, N. (2018). Does financial reporting quality vary across firm life Cycle? Available at SSRN: https://doi.org/10.2139/ssrn.3233512

Lambert, R., Leuz. C., \& Verrecchia. R. (2007). Accounting information, disclosure, and the cost of capital. Journal of Accounting Research, 45(2), 385-420. https://doi.org/ 10.1111/j.1475-679x.2007.00238.x

Larrán, M., Andrades, J., \& Herrera, J. (2018). An examination of attitudes and perceptions of Spanish business and accounting students toward corporate social responsibility and sustainability themes. Revista de Contabilidad, 21(2), 196-205. https://doi.org/10.1016/j.rcsar.2018. 02.001

Lev, B., Petrovits, C., \& Radhakrishnan, S. (2009). Is doing good good for you? How corporate charitable contributions enhance revenue growth. Strategic Management Journal, 72(4), 1785-1824, https://doi.org/10. $1002 /$ smj. 810

Levy, D. L., \& Kaplan, R. (2009). Corporate social responsibility and theories of global governance. Handbook of corporate social responsibility. Oxford: Oxford University Press.

Lins, K. V., Servaes, H., \& Tamayo. A. (2017). Social capital, trust, and firm performance: The value of corporate social responsibility during the financial crisis. The Journal of Finance, 72(4), 1785-1824. https://doi.org/10.1111/ jofi. 12505

Linthicum, C., Reitenga, A. L., \& Sanchez, J. M. (2010). Social responsibility and corporate reputation: The case of the Arthur Andersen Enron audit failure. Journal of Accounting and Public Policy, 29(2), 160-176. https://doi. org/10.1016/j.jaccpubpol.2009.10.007

Liu, L., Li. S., \& Opara, M. (2018). Corporate social responsibility and strategic company behaviour: CVS Health's discontinuation of tobacco products. Corporate Social Responsibility and Environmental Management, 25(6), 12931305. https://doi.org/10.1002/csr.1639

Lopes, A. B., Walker, M., \& da Silva, R. L. M. (2016). The determinants of firm-specific corporate governance arrangements, IFRS adoption, and the informativeness of accounting reports: Evidence from Brazil. Journal of International Accounting Research, 15(2), 101-124. https: //doi.org/10.2308/jiar-51532

López-González, E., Martinez-Ferrero, J., \& García-Meca, E. (2019). Does corporate social responsibility affect earnings management? Evidence from family firms. Revista de Contabilidad-Spanish Accounting Review, 22(2), 233247. [https://doi.org/10.6018/rcsar.349601]

Ma, M. (Shuai). (2017). Economic links and the spillover effect of earnings quality on market risk. The Accounting Review, 92(6), 213-245. https://doi.org/10.2308/ accr-51715

Martínez-Ferrero, J., Ruiz-Cano, D., \& García-Sánchez, I.-M. (2015). The causal link between sustainable disclosure and information asymmetry: The moderating role of the stakeholder protection context. Corporate Social Responsibility and Environmental Management, 23(5), 319-332. https://doi.org/10.1002/csr.1379

Mattingly, J. E., \& Berman, S. L. (2006). Measurement of corporate social action. Business \& Society, 45(1), 20-46. https://doi.org/10.1177/0007650305281939

Muttakin, M. B., Mihret, D. G., \& Khan, A. (2018). Corporate political connection and corporate social respons- ibility disclosures. Accounting, Auditing \& Accountability Journal, 31(2), 725-744. https://doi.org/10.1108/ aaaj-06-2015-2078

Mohammad, S., \& Husted, B. W. (2019). Law-abiding organizational climates in developing countries: The role of institutional factors and socially responsible organizational practices. Business Ethics: A European Review, 28(4), 476493. https://doi.org/10.1111/beer.12228

Nair, R., Muttakin, M., Khan, A., Subramaniam, N., \& Somanath, V. S. (2019). Corporate social responsibility disclosure and financial transparency: Evidence from India. Pacific-Basin Finance Journal, 56, 330-351. https: //doi.org/10.1016/j.pacfin.2019.06.015

Narwal, M., \& Singh, R. (2013). Corporate social responsibility practices in India: a comparative study of MNCs and Indian companies. Social Responsibility Journal, 9(3), 465-478. https://doi.org/10.1108/srj-11-2011-0100

Naughton, J. P., Rogo, R., Sunder, J., \& Zhang, R. (2018). SEC monitoring of foreign firms' disclosures in the presence of foreign regulators. Review of Accounting Studies, 23(4), 1355-1388. https://doi.org/10.1007/ s11142-018-9467-x

Nelson, K. K., \& Pritchard, A. C. (2016). Carrot or Stick? The Shift from voluntary to mandatory disclosure of risk factors. Journal of Empirical Legal Studies, 13(2), 266297. https://doi.org/10.1111/jels.12115

Pandit, S., Wasley, C. E., \& Zach, T. (2011). Information externalities along the supply chain: The economic determinants of suppliers' stock price reaction to their customers' earnings announcements. Contemporary Accounting Research, 28(4), 1304-1343. https://doi.org/10.1111/j. 1911-3846.2011.01092.x

Paredes-Gazquez, J. D., Rodriguez-Fernandez, J. M., \& de la Cuesta-Gonzalez, M. (2016). Measuring corporate social responsibility using composite indices: Mission impossible? The case of the electricity utility industry. Revista de Contabilidad-Spanish Accounting Review, 19(1), 142-153. https://doi.org/10.1016/j.rcsar.2015.10.001

Peloza, J. (2006). Using corporate social responsibility as insurance for financial performance. California Management Review, 48(2), 52-72. https://doi.org/10.2307/ 41166338

Prior, D., Surroca, J., \& Tribó, J. A. (2008). Are socially responsible managers really ethical? Exploring the relationship between earnings management and corporate social responsibility. Corporate Governance: An International Review, 16(3), 160-177. https://doi.org/10.1111/ j.1467-8683.2008.00678.x

Rajgopal, S. (2019). Integrating practice into accounting research. Available at SSRN: https://doi.org/10.2139/ssrn. 3368611

Ramanna, K. (2013). A Framework for research on corporate accountability reporting. Accounting Horizons, 27(2), 409-432. https://doi.org/10.2308/acch-50412

Ramchander, S., Schwebach, R. G., \& Staking, K. (2012). The informational relevance of corporate social responsibility: evidence from DS400 index reconstitutions. Strategic Management Journal, 33(3), 303-314. https://doi. org/10.1002/smj.952

Robinson, J. R., Xue, Y., \& Yu, Y. (2011). Determinants of disclosure noncompliance and the effect of the SEC Review: Evidence from the 2006 mandated compensation disclosure regulations. The Accounting Review, 86(4), 14151444. https://doi.org/10.2308/accr-10033

Rothenhoefer, L. M. (2018). The impact of CSR on corporate reputation perceptions of the public-A configurational 
multi-time, multi-source perspective. Business Ethics: A European Review, 28(2), 141-155. https://doi.org/10. 1111/beer.12207

Schnietz, K. E., \& Epstein, M. J. (2005). Exploring the financial value of a reputation for corporate social responsibility during a crisis. Corporate Reputation Review, 7(4), 327-345. https://doi.org/10.1057/palgrave. crr. 1540230

Scholtens, B., \& Kang, F.-C. (2012). Corporate social responsibility and eearnings management: Evidence from Asian economies. Corporate Social Responsibility and Environmental Management, 20(2), 95-112. https://doi.org/10. 1002/csr. 1286

Schwarz, N., \& Clore, G. L. (1983). Mood, misattribution, and judgments of well-being: Informative and directive functions of affective states. Journal of Personality and Social Psychology, 45(3), 513-523. https://doi.org/10. 1037/0022-3514.45.3.513

Securities and Exchange Commission (SEC). (2015), Division of corporation finance - Filing review process. https://www.sec.gov/divisions/corpfin/cffilingreview. htm/\#.VQBzofl4q-1

Securities and Exchange Organization (SEO). (2007), Regulations on disclosure of information by the companies registered with the organization. Retrieved from https: //www.RDIS.ir

Securities and Exchange Organization (SEO). (2014), Iran capital market annual report 2014. Retrieved from https://en.seo.ir/Page/295/ Iran-Capital-Market-Annual-Report.

Sen, S., \& Bhattacharya, C. B. (2001). Does doing good always lead to doing better? Consumer reactions to corporate social responsibility. Journal of Marketing Research, 38(2), 225-243. https://doi.org/10.1509/jmkr. 38.2.225.18838

Servaes, H., \& Tamayo, A. (2013). The impact of corporate social responsibility on firm value: The role of customer awareness. Management Science, 59(5), 10451061. https://doi.org/10.1287/mnsc.1120.1630

Shahab, Y., \& Ye, C. (2018). Corporate social responsibility disclosure and corporate governance: empirical insights on neo-institutional framework from China. International Journal of Disclosure and Governance, 15(2), 87103. https://doi.org/10.1057/s41310-018-0038-y

Shumsky, T. (2016), "Visa's Chief Accountant on receiving - and sending - comment letters", WSJ.com (August 31). Available at http://blogs.wsj.com/cfo/2016/ 08/31/visa $\% 2$ dinc $\% 2$ ds $\% 2$ dchief $\% 2$ daccountant $\%$ 2don $\% 2$ dreceiving $\% 2$ dand $\% 2$ dsending $\% 2$ dcomment $\%$ 2dletters/

Siegel, D. S., \& Vitaliano, D. F. (2007). An Empirical Analysis of the Strategic Use of Corporate Social Responsibility. Journal of Economics \& Management Strategy, 16(3), 773-792. doi:10.1111/j.1530-9134.2007.00157.x

Starks, L. T. (2009). EFA Keynote Speech: "Corporate governance and corporate social responsibility: What do investors care about? What should investors care about?". Financial Review, 44(4), 461-468. https://doi.org/10. 1111/j.1540-6288.2009.00225.x

Su, W., Peng, M. W., Tan, W., \& Cheung, Y.-L. (2014). The signaling effect of corporate social responsibility in emerging economies. Journal of Business Ethics, 134(3), 479-491. https://doi.org/10.1007/s10551-014-2404-4

Surroca, J., \& Tribó, J. A. (2008). Managerial entrenchment and corporate social performance. Journal of Business Finance \& Accounting, 35(5-6), 748-789. https://doi.org/ 10.1111/j.1468-5957.2008.02090.x

Tan, W., Tsang, A., Wang, W., \& Zhang, W. (2020). Corporate social responsibility (CSR) disclosure and the choice between bank debt and public debt. Accounting Horizons, 34 (1), 151-173. https://doi.org/10.2308/acch-52631

Tomas Siueia, T., \& Wang, J. (2019). La asociación entre las actividades de responsabilidad social corporativa y la calidad de los ingresos: Evidencia de la industria extractiva. Revista de Contabilidad-Spanish Accounting Review, 22(1), 112-121. https://doi.org/10.6018/rc-sar.22.1.354361

Unruh, G., Kiron, D., Kruschwitz, N., Reeves, M., Rubel, H., \& zum Felde, A. M. (2016). Investing for a sustainable future. MIT Sloan Management Review, 57(4).

Wang, H., \& Qian, C. (2011). Corporate philanthropy and corporate financial performance: The roles of stakeholder response and political Access. Academy of Management Journal, 54(6), 1159-1181. https://doi.org/10.5465/ amj.2009.0548

Yao, Y., \& Xue, S. (2019). Comment letters and internal control opinion shopping. China Journal of Accounting Studies, 7(2), 214-244. https://doi.org/10.1080/21697213. 2019.1676066

Ye, K., \& Zhang, R. (2011). Do lenders value corporate social responsibility? Evidence from China. Journal of Business Ethics, 104(2), 197-206. https://doi.org/10.1007/ s10551-011-0898-6

Xu, B., \& Yang, Y. C. (2019). Does corporate social responsibility facilitate public debt financing? Available at SSRN: https://doi.org/10.2139/ssrn.3442970

Zhang, X. F. (2006). Information uncertainty and stock returns. The Journal of Finance, 61(1), 105-37. https: //doi.org/10.1111/j.1540-6261.2006.00831.x 